\title{
Nation-Building through War
}

\author{
Nicholas Sambanis \\ Department of Political Science \\ Yale University \\ Stergios Skaperdas \\ Department of Economics \\ University of California, Irvine \\ William Wohlforth \\ Department of Government \\ Dartmouth College
}

December 12, 2014

\begin{abstract}
How do the outcomes of international wars affect domestic social change? In turn, how do changing patterns of social identification and domestic conflict affect a nation's military capability? Models that link structural variables, power politics, and the individuals that constitute states are in problematically short supply. We begin to address this gap with a model that draws on experimental results in social psychology and behavioral economics to recapture a lost building block of the classical realist theory of statecraft: the connections between the outcomes of international wars, patterns of social identification and domestic conflict, and the nation's future war-fighting capability. We show that, when inter-state war can significantly increase a state's international status at the expense of its competitor, peace is less likely to prevail in equilibrium because, by winning a war and raising the nation's status, leaders induce individuals to identify nationally, thereby reducing internal conflict by increasing investments in state capacity. In certain settings, it is only through the anticipated social change that victory can generate that leaders can unify their nation; and the higher anticipated payoffs to national unification makes leaders fight international wars that they would otherwise choose not to fight. We use the case of German unification after the Franco-Prussian war to demonstrate the model's value-added and illustrate the interaction between social identification, nationalism, state-building and the power-politics of interstate war.
\end{abstract}

JEL codes: D73, D74, H10, F50

Keywords: State capacity, identity, nationalism, conflict. 


\section{Introduction}

A century ago the leaders of Austria-Hungary determined that the nation-building efforts of Serbia were a mortal threat to their empire. A series of military victories in the Balkan Wars had so enhanced Serbia's prestige that increasing numbers of southern Slavs - not just Serbs, but Croats and Slovenes as well-came to identify with the idea of a Serbdominated Yugoslavia whose existence could only come at Austria-Hungary's expense (Banac 1983). Archduke Franz Ferdinand's assassination in June 1914 was a convenient pretext to settle accounts with Serbia once and for all, through war. Meeting at a palace outside St. Petersburg in July 1914 Czar Nicholas II and his ministers decided to mobilize their army in response to Austria-Hungary's move, risking war with Germany even though Russia's military program was expected to improve its odds if war could be delayed for a few more years. Accounts of the decision stress Russian leaders' obssessive preoccupation with their empire's great power status, which they expected to suffer an irreparable blow should they fail to stand by their Serbian ally (Lieven 1983). International status competition was inexorably entwined with the period's revived Russian nationalism: "Nationalist ideology... insisted that Russia must be a great power... and demonstrated its ability to unite the nation, apparently able to integrate an old society riven by economic, social and political

divisions. In a unanimity of view based for the most part on ideology alone, the wealthy and educated classes put themselves at the service of the government. The capacity of nationalism to mitigate internal conflict allowed Tsarist Russia to go to war" (Geyer 1987, $317)$.

This interaction between victory in war, the social identification of the individuals that comprise states, and the power and security of those states helped prime Europe for war in the summer 1914. Yet in the outpouring of scholarly work marking the Great War's centennial this interaction receives short shrift, in part because dominant theories in political science point in other directions. Since the 1980s the study of war has been shaped by debates inspired by neorealism, with its focus on endemic power-seeking among states made insecure 
by anarchy. Much of what we know about war is the result of efforts to elaborate this account or fix its perceived flaws. Neorealism's long shadow lends the study of war a structural bias, which we seek to complement with a theory focusing on the links between leaders' strategic choices on the one hand and the psychological foundations of individuals' preferences on the other hand. These links, as the fateful decisions of the summer of 1914 suggest, are important and overlooked pieces of the war puzzle.

We propose a new "second-image reversed" theory of war in which the gains and costs of war are functions of the domestic political consequences of its anticipated outcome. We retain key tenets of the rationalist theory of war, but model war initiation as a decision that can be traced to psychological effects of war outcomes. We draw on the experimental literature in social psychology and behavioral economics to propose a model in which individuals' identification with their nation is contingent on the nation's relative status. In turn, status is a function of military outcomes. We show that, when state capability depends partly on the strength of nationalist sentiment, war becomes a vehicle to induce national identification by increasing the nation's status relative to rivals. We also show how nation-building ${ }^{1}$ and state-building processes depend on each other: increased national identification due to victory in war encourages investments in state capacity, which reduce the costs of domestic conflict, reinforcing national identity. The Austria-Hungary and Russia examples suggest that these relationships also work in reverse: military defeat and loss of national status may weaken national identification. While our theory is compatible with the classic "warmade-the-state" perspective, we argue that effective state-building is partly endogenous to a pre-existing reservoir of commonalities among social groups in a given territory and that victory in war can fill that reservoir to induce cooperation among groups that might otherwise be in conflict, not seeing themselves as part of the same nation. No extant model of war captures this mutually reinforcing relationship between structural variables (capabilities, war

\footnotetext{
${ }^{1}$ Nation-building is the process of creating-and identifying with-a common national identity to legitimize the authority of the state. In modern states legitimate authority "is connected to popular rule, to majorities. Nation-building is the process through which these majorities are constructed" (Mylonas 2013, 17).
} 
outcomes) and both institutional and ideational factors. ${ }^{2}$

Our theory thus moves beyond the common juxtaposition of realist, domestic-institutional and constructivist approaches in IR. The standard critique of realist theory by scholars who emphasize the analytical costs of black-boxing the state is that domestic institutions and group interests push leaders to prioritize personal political survival over state interests (Bueno de Mesquita and Smith 2012, 177). By contrast, many influential constructivist approaches retain a "holistic," systemic perspective to argue that state interests and identities co-evolve on the basis of an inter-subjective understanding of the world (Wendt 1999; Finnemore 1996). We share with constructivists the view that identities are socially constructed and that they shape state interests; and we share with institutionalists the view that leaders are strategic in pursuing their interests. But we augment both approaches by modeling an individualist theory of identity formation that is shaped in part by the exigencies of competition at the systemic level. Leaders interested in survival understand the need for power projection and international status enhancement; and these distinctly realist preoccupations induce them to forge a stronger national identity at home. The social construction of national identities is therefore intertwined with the production of state power.

We begin by introducing the theory informally and situating it in the literature. We then build the model formally, presenting a baseline version and then adapting it to the richly documented and historically important case of the Franco-Prussian War. We then show how the model's predictions identify causal mechanisms at the core of a century of historiography on that war that are missed by extant theories. We conclude with a summary of our theory's implications for the study of war in international relations.

\footnotetext{
${ }^{2}$ There are several related approaches, such as Posen's (1993) pioneering study exploring the relationship between changes in the technology of war, military victory and nationalism. Wimmer (2013) analyzes the interplay between nationalism and inter-state war and models how political modernization shifts allegiances from regional/local groupings to the nation. Mylonas (2013) explains how specific nation-building policies (i.e. the choice to assimilate, accommodate, or exclude a "non-core" group) is determined by the host state's foreign policy goals as it competes with external powers that can support those non-core groups. Also complementary to ours are analyses of the effects of external conflict on the domestic political economy (see especially Dincecco, Federico, and Vindigni 2011).
} 


\section{War, Social Identity and the State}

Individuals care not just about their own material interest, but also about the social groups with which they identify (Taijfel and Turner 1986). They derive utility from belonging to larger social groupings, preferring, all else equal, to identify with higher-status groups and favoring in-group members at the expense of out-group members. These results bear directly on the foundational concept of state power, a central but largely black-boxed explanatory variable in realist theories of war. We unpack that box and argue that conflict outcomes that generate higher status for a state in international politics can induce social cohesion through national identification, which can enhance state power. This in turn can further increase national status and solidify national identification in a virtuous circle. State-building processes are part of that dynamic as investments in national institutions increase with national identification.

Though novel in a modern context, our argument about the importance of status-seeking and social identification would have seemed common-sensical judged by the standards of pre20th century writings on international politics. All of the classical thinkers on whom modern realists draw - Thucydides, Hobbes, Machiavelli, Rousseau, the theorists of raison d'etat and realpolitik - saw prestige or status as a foundational human motivation (see Markey 1999 for a review). In the holistic approach to theory that typified classical thinking, individuals' affection for prestige was one factor that could drive them into dangerously competitive behavior, an impulse that Hobbes argued could be overcome only by "a common power to keep them all in awe" (Leviathan, chapter 13). A causal chain was evident to classical theorists connecting the sources of internal state coherence and power, on the one hand, and the competitive drive for position among states on the other.

The very term Realpolitik originally concerned precisely this connection between interstate power politics and intra-state identity politics. Ludwig von Rochau coined the term in 1853 to describe the policies of power and prestige that Prussia would have to follow to unify the Germans in one state (Meinecke 1924, 396). In Economy and Society, Max Weber 
brought these themes together in a theory linking a nation's international status to individuals' dispositions toward particularistic or national forms of identification. "The prestige of power means in practice the glory of power over other communities," Weber held, " .. [and] it is on this prestige that the consensus of specific action of legitimacy is founded" (Weber 1924 [1978], 911; Collins 1986, chap. 6). But this holistic approach was progressively abandoned, first when post-war realists such as Carr and Morgenthau maintained the focus on inter-state prestige seeking, but ignored its implications for domestic identity and cohesion. Their successors, neorealists such as Waltz and Mearsheimer, jettisoned status as a state preference entirely in favor of an exclusive focus on security.

In recovering for modern scholarship classical realist insights on the interaction between inter-state and domestic politics, our theory also parts company with diversionary war theory, which assumes that "the essential purpose of diversionary action [at the international level] is to enhance domestic political survival - to counter internal threats to political power, not external ones to state survival, security, or other national interests" (Fravel 2010, 311). In our approach, domestic politics makes leaders more conflict-prone, but it is the logic of international competition that focuses leaders' attention to domestic factors in the first place.

To summarize what follows, we refocus attention on status competition and social identification by presenting a model of interstate conflict in which two countries can decide to go to war or remain at peace, and the outcome rests on the expected effect of victory on domestic patterns of social identification. The two countries have latent claims over territory but war would never occur in the absence of the benefits of national identification that might follow war. One of the countries is divided in two social groups that are in conflict. The intensity of inter-group (domestic) conflict depends on state capacity, which in turn depends on whether group members identify primarily with their group or with the nation. If they identify with their group, then investments in state capacity are low and conflict is more intense. If both groups identify with the nation, then investments in state capacity are higher and conflict less intense. These domestic groups are less likely to identify with the 
nation the larger is their social distance from it and the lower the nation's status. Victory in inter-state war increases the nation's status and can produce higher payoffs by inducing people to identify nationally, investing more in state capacity. This expectation drives rational elites to invest more heavily in arms, which makes international war more likely than would be the case if the domestic social consequences of war are not considered. We provide a formal model of that process and show how the model is consistent with the case of the Franco-Prussian war. The domestic component of the model is a reduced form combination of the identity-and-conflict model of Sambanis and Shayo (2013) and the dynamic model of peace-and-war with endogenous state capacity of McBride et.al. (2011). Our model extends and complements both of its antecedents and embeds the domestic interactions in a model of inter-state conflict that endogenizes war outcomes to social identification.

\section{Domestic Interactions: Social Identification, State Capacity and Internal Conflict}

A body of empirical work in economics and social psychology examines how group membership affects individual behavior (see Sambanis et al. 2012 for a review) and documents a tendency for ingroup bias (the preferential treatment of members of one's group); higher levels of cooperation with ingroup than with outgroup members; and conformity to ingroup norms. This type of behavior corresponds to what we call social identification. The determinants of social identification have been studied intensively using the Minimal Group Paradigm (Tajfel et al. 1971) - experiments in which subjects are assigned to groups and then make anonymous allocation decisions between an ingroup and an outgroup member. Researchers find that highlighting a common trait of the ingroup while contrasting it with

the corresponding trait of an outgroup results in a perception of greater similarity to the ingroup and leads subjects to favor ingroup members (see Brewer 1979 and Bourhis and Gagnon 2001 for reviews). A number of studies also measure the effect of status comparisons on ingroup bias. A meta analysis of 92 experimental studies of status effects concludes 
that high-status group members favor their ingroup over the outgroup significantly more than do low-status group members (Bettencourt et al. 2001).

Drawing on those empirical studies and following Sambanis and Shayo (2013) and Shayo (2009), we say that an individual identifies with group $J$ if, in addition to material payoffs, he cares about (a) the status of group $J$ (and in particular the payoffs of ingroup members relative to the payoffs of outgroup members); and (b) his similarity to other members of that group (i.e. social distance). We use the concept of social identification to bridge the realm of comparative politics - where social identities such as ethnicities and nations have been studied intensively - with the realm of international relations. We share a constructivist view of identity formation and change and we show how the social environment that shapes identities is in turn shaped by war and status competition at the systemic level. We model a process in which groups can identify either with their nation or along ethnic, religious, or regional lines and argue that their social identities are determined in equilibrium as a function of social distance and inter-group status comparisons. Distance from the nation is determined by cultural differences between the group and other groups that are part of the same nation. Group status is determined via comparisons to other groups (Tajfel and Turner 1986). In our model, inter-state competition shapes the outcome of status comparisons that will drive the results.

We model two regionally or ethnically defined groups within a single country that compete over resources. Half of the population of the country are members of group $A$ and the other half are members of group B. The population and elites (reflecting the population's preferences) can identify either with their region or with the nation by virtue of sharing the attributes of both groups. ${ }^{3}$ In our model, identification with a group (nation) includes the possibility of "fighting" on behalf of the group (nation). This fighting can range from

\footnotetext{
${ }^{3}$ We focus on elite choices, but a model of individuals would produce substantively similar results. We prefer to model elites because decisions to go to war are typically made by leaders and do not depend on how much effort individual citizens want to apply. Elites are forward-looking and can engage in war so as to induce national identification. But they are constrained by the social preferences of the people they represent and we assume that those preferences are not infinitely malleable.
} 
outright war to non-violent conflict such as lobbying and rent-seeking with efforts that are costly and subtract from material payoffs. Social identification determines material payoffs through several channels: state capacity; the level of conflict; and, INDIRECTLY, social status. [NEW TEXT ADDED BELOW, ADAPTED FROM EARLIER VERSION (ALL DISCUSSION OF STATE CAPACITY HAD SOMEHOW DISAPPEARED):] State capacity captures the strength of institutions and the ability of the state to mediate in disputes between the two groups and reduce conflict. Part of this involves rule of law institutions, or what Besley and Persson (2011) call legal capacity, but other forms of state capacity also conform to the way modeled here (see McBride et.al., 2011, for a discussion). State capacity partly depends on the investment choices of the two groups as well as on identities.

The sequence of moves is the following: ${ }^{4}$

1. Each group decides whether to identify nationally $(N)$ or ethnically $(A, B)$.

2. Given identities from stage 1, each group makes a choice about how much to contribute to state capacity (denoted by $I_{A}$ and $\left.I_{B}\right)$.

3. Given identities and state capacity from stages 1 and 2, the two groups make costly conflict efforts $\left(e_{A}\right.$ and $\left.e_{B}\right)$ and the payoffs of each group are determined.

For ease of exposition we develop the full domestic part of our model in the Appendix and in the text we only discuss the reduced form payoffs in stage 1 (that take into account the equilibrium outcomes of the subsequent stages). When AT LEAST ONE SIDE IDENTIFIES WITH own group, then the material payoff of each group equals $v$. (In the Appendix we show how this quantity depends on productive potential, the costs of conflict, and investments in state capacity.) The group that identifies with the nation also receives a non-material payoff, given by $s(=\sigma-\Delta)$, which captures the status difference associated with identifying with the nation as opposed to the (sub-national) group minus the DISTANCE cost associated

\footnotetext{
${ }^{4}$ We abstract from collective action problems within groups, so we assume that the elites help the group coordinate to a single identity.
} 
with national identification for any group member. THE parameter $s$ can be greater or less than zero; it is normalized to zero for the group that identifies along group lines.

When both groups identify with the nation, they both receive payoffs of $V(s)+s$, where $V(s)$ represents the material payoff under national identification. When $s \leq 0, V(s)=v$, the material payoff under group identification. In such a case, the status minus distance parameter is too low to induce the investments in state capacity that would lower conflict costs relative to the case of group identification. When $s>0, V(s)>v$ and is an increasing function of $s$; in that case investments in state capacity are higher than in the case under group identification so as to lower the costs of domestic conflict and increase material payoffs under national identification. The greater the status of the nation (relative to the group) and the lower is the perceived distance from the nation the higher are the investments in state capacity and the higher are the material payoffs under national identification. (In the Appendix we fully develop the foundations of this model.)

Thus, as of stage 1 our game is represented by the following matrix:

$$
\begin{array}{ccc} 
& N & B \\
N & V(s)+s, V(s)+s & v+s, v \\
A & v, v+s & v, v
\end{array}
$$

When $v>V(s)+s$ (which occurs for all $s<0$ ), the unique (and dominant-strategy) equilibrium of this matrix game is for both sides to identify with their own group. When $v<$ $V(s)+s$ (which occurs for all $s>0$ ), the unique (also dominant-strategy) EQUILIBRIUM is to identify with the nation..$^{5}$

The matrix game in (1) encapsulates the somewhat complex domestic interactions we examine in the Appendix, yet it is simple enough [DELETED HERE A FEW WORDS] to analyze the inter-state interactions that we turn to next. We have emphasized the linkage between, on the one hand, national status and group distance and, on the other hand, state capacity and the higher material benefits that national identification may generate. Other,

\footnotetext{
${ }^{5}$ When $v=V(s)+s$, under $s=0$, all payoffs are identical and all outcomes are equilibria. In addition to this being generically a rare case, it is also not interesting as social identification has no effect on what occurs in inter-state disputes; we, therefore, disregard this case.
} 
analytically distinct, mechanisms - such as the higher conflict costs that status competition under group identification brings (Sambanis and Shayo, 2013) - CAN also yield essentially the same matrix game AS in (1).

While facing internal conflict, the country we model is also engaged in inter-state competition that can result in war. In the next section, we embed this model in an inter-state conflict model with three possible realized states of the world: peace $(p)$, victory after war $(\nu)$, and loss after war $(l)$. The status and distance parameters take different values depending on the state of the world so that $\sigma \in\left\{\sigma^{l}, \sigma^{p}, \sigma^{\nu}\right\}$ and $\Delta \in\left\{\Delta^{l}, \Delta^{p}, \Delta^{\nu}\right\}$. Clearly the variable $s$ will also be taking three values $s \in\left\{s^{l}, s^{p}, s^{\nu}\right\}$ (with $s^{i} \equiv \sigma^{i}-\Delta^{i}$, where $i=p, \nu, l$ ).

\section{Inter-state Conflict with Endogenous Social Identi- fication}

Consider two countries, denoted by $F$ and $G$, for which the immediate object of conflict is a dispute over territory. Let $d$ be the total value of the disputed territory with the status quo (or, Peace) involving $F$ and $G$ holding $(1-\beta)$ and $\beta$ shares, respectively, of the total value $(\beta \in[0,1])$. Each country has the choice of Peace or War, with Peace prevailing only if both countries choose it. For simplicity, suppose that country $F$ does not face any problems of internal cohesion and national identification of the type we have just described, but $G$ does. That is, subsequent to the choice between Peace and War, the leaders of country $G$ face the choice described in (1). (Given the symmetry of the model, it does not matter whether the leader belongs to group $A$ or $B$.)

To be precise, the sequence of moves that we consider is as follows:

1. F and $G$ simultaneously choose either War or Peace. If both choose Peace, then Peace prevails. If at least one country chooses War, then War occurs and each country pays cost $c>0 .{ }^{6} G$ wins with probability $p \in(0,1)$ and $F$ wins with probability $1-p$.

\footnotetext{
${ }^{6}$ There are many different ways of modeling the cost of war but all lead to the same qualitative results. Alternatives that have been exlored in Garfinkel and Skaperdas (2000) and McBride and Skaperdas (2007) include the possibility of losing a fraction of current output or losing a constant fraction of output forever,
} 
2. After Peace, victory for $G$ after War, or loss for $G$ after War, $G$ plays the game in (1). [CHANGED TWO WORDS HERE.]

Normally, it would be very hard to induce War in static situations with positive costs of warfare, in the absence of commitment problems, and under complete information, which is the case that we examine here (see, for example, Fearon, 1995; Skaperdas, 2006). As we shall shortly show, however, this is no longer assured in our setting. Whether Peace prevails partly depends on what occurs within country $G$ in the case of Peace and after victory or loss in case of War which, in turn, partly depends on the values that the status and distance parameters (as summarized by $s^{i}$ ) take in each case relative to other parameters. It is reasonable to suppose the following about the relationship of the three parameters: ${ }^{7}$

$$
s^{\nu}>\max \left\{s^{p}, s^{l}\right\}
$$

We assume that both countries behave in a risk-neutral fashion. Moreover, to rule out the possibility of War due to indivisibilities, we allow for perfectly divisible transfers from one country to the other. The payoffs of $F$ under Peace $(P)$ and War $(W)$ are as follows:

$$
\begin{aligned}
V_{P}^{F} & =(1-\beta) d-t \\
V_{W}^{F} & =(1-p) d-c
\end{aligned}
$$

where $t$ denotes the transfer from $F$ to $G$ (which is a negative number if the transfer is the other way) and the payoff of $F$ in the case of loss in War, that occurs with probability $p$, is normalized to be 0 . Also note that we have not included other sources of payoffs of $F$ that might be common to both War and Peace since they don't affect the final choice.

The payoffs of $G$ under Peace and War depend on what can be expected to occur under the contingencies in stage 2. We examine each of five possible cases focusing on whether in addition to allowing the choice or levels of arming.

${ }^{7}$ The values that the status variable takes can be related in the following fashion: $\sigma^{\nu} \geq \sigma^{p} \geq \sigma^{l}$. Similarly, we expect the distance between groups to become smaller after victory in War compared to that under Peace $\left(-\Delta^{p} \leq-\Delta^{\nu}\right)$. It might be the case, however, that distance might also decrease, at least temporarily, after a loss at War, so that $-\Delta^{p} \leq-\Delta^{l}$, thus making the relationship between $s^{p}$ and $s^{l}$ ambiguous, and leaving (2) as a reasonable minimal assumption about the relationship between the three variables. 
Peace would ever be feasible, regardless of the specific game that determines the transfer $t$. For brevity, we only go over two cases here, relegating the other cases to our Supplementry Appendix (but report all results in Proposition 1).

\section{Case I: Group identification always occurs in $G$}

This is a useful benchmark and occurs when $v \geq V\left(s^{i}\right)+s^{i}$ for all $i=p, \nu, l$. As shown in (1)[CHANGED SLIGHTLY HERE], IN this case the internal equilibrium in country $G$ is always group identification. Then, payoffs under Peace and War for $G$ are:

$$
\begin{aligned}
V_{P}^{G_{I}} & =v+\beta d+t \\
V_{W}^{G_{I}} & =p(v+d)+(1-p) v-c=v+p d-c
\end{aligned}
$$

For Peace to occur, we need to have both $V_{P}^{F} \geq V_{W}^{F}$ and $V_{P}^{G_{I}} \geq V_{W}^{G_{I}}{ }^{8}$. Given risk neutrality and the allowance for transfers from one country to another the problem becomes one of $V_{P}^{F}+V_{P}^{G_{I}} \geq V_{W}^{F}+V_{W}^{G_{I}}$, or that the total payoffs under Peace are at least as high as those under War, which given (3)-(6) imply:

$$
v+d \geq v+d-2 c
$$

Since for $c>0$ this inequality is always satisfied (as a strict inequality), there is always a transfer $t$ that would make the payoffs of both players at least as high as those under War. That is, when ethnic identification always occurs in country $G$, Peace in the international conflict is always an equilibrium because victory or loss in War do not affect the domestic conflict's payoffs and equilibrium.

\section{Case II: National identification in $G$ occurs only after victory in War}

This case occurs when $V\left(s^{\nu}\right)+s^{\nu}>v \geq \max \left\{V\left(s^{p}\right)+s^{p}, V\left(s^{l}\right)+s^{l}\right\}$. [DELETED A FEW WORDS HERE] In this case the internal equilibrium in country $G$ is national identification after victory in War and group identification under Peace or after loss in War. Then, the

\footnotetext{
${ }^{8}$ Note that, for this as well as the other cases, War is always an equilibrium since if one side decides to go to War it is a best response for the other side to choose War as well. Here as well as later we focus on the feasibility of a Peace equilibrium.
} 
payoffs under Peace and War in this case are:

$$
\begin{aligned}
V_{P}^{G_{I I}} & =v+\beta d+t \\
V_{W}^{G_{I I}} & =p\left(V\left(s^{\nu}\right)+s^{\nu}+d\right)+(1-p) v-c
\end{aligned}
$$

Again, given risk neutrality and the allowance for transfers from one country to another the problem becomes one of $V_{P}^{F}+V_{P}^{G_{I I}} \geq V_{W}^{F}+V_{W}^{G_{I I}}$, which implies:

$$
\begin{aligned}
& v+d \geq p\left(V\left(s^{\nu}\right)+s^{\nu}\right)+(1-p) v+d-2 c \\
& \text { or } 2 c \geq p\left[V\left(s^{\nu}\right)+s^{\nu}-v\right]
\end{aligned}
$$

Given that in this case $V\left(s^{\nu}\right)+s^{\nu}>v$, the right-hand-side of (8) is positive and, therefore, there are always low enough costs of War (i.e., c) for which Peace is never feasible. Note that there is no role for the disputed territories $(d)$ in creating any incentives for War. Even if $d$ were 0 , country $G$ woud have an incentive to instigate War (provided of course that the costs are low enough) in order to reap the benefits of national identification.

There are three additional cases (examined in the Supplementary Appendix): Case III, in which Group identification occurs only after loss in War; Case IV, in which Group identification occurs only when there is Peace; and Case V, in which WAR ALWAYS OCCURS [PREVIOUSLY THERE WAS TYPO HERE - REPETITION OF CASE IV.]. The results from all cases are summarized in Proposition 1.

Proposition 1 (i) When group identification is always the equilibrium in G (case I), Peace is always feasible.

(ii) When national identification is the equilibrium after victory in War and group identification is the equilibrium under Peace in $G$ (cases II and IV), War always occurs when its costs (c) are low enough. The higher is the probability of victory ( $p)$ for $G$ and the higher is the status $\left(\sigma^{\nu}\right)$ and the lower the distance cost under victory $\left(\Delta^{\nu}\right)$, the less likely is Peace.

(iii) When group identification is the equilibrium in $G$ only after loss in War or when national identification is always an equilibrium in $G$ (cases III and V), Peace is not feasible 
only if the probability of victory (p) for G or [CHANGED "and" TO "or".] the status minus distance cost under victory $\left(s^{\nu}=\sigma^{\nu}-\Delta^{\nu}\right)$ are high enough.

In sum, WHEN WE ADD TO the standard realist SETTING of inter-state competition under anarchy a psychological mechanism linking war, status, state capacity, and domestic intra-group conflict, we can account for war in situations where it would otherwise not occur. This mechanism applies to settings where inter-state conflict occurs in the shadow of domestic conflict. Such domestic conflict is implicit whenever individuals' allegiance is divided between nested social identities and sub-national social groups compete over resources. Inter-state conflict can shape patterns of domestic conflict by pushing individuals to identify nationally or parochially (along ethnic, regional, or class lines). When individuals identify with their ethnic or other narrowly defined social group, this can diminish the state's ability to mobilize resources or public support for inter-state war.

The scope conditions for the theory are broad. It captures the tradeoffs between domestic and external conflict in multi-ethnic states, federations, conglomerates, or empires where individuals' allegiances do not always align with the state and where domestic conflict over resources, autonomy, or self-determination can weaken the state's power as it competes in the arena of international politics. We mainly require that the national identity be open to any group in the country; and for nationalism to exist as an ideology (so that national identification would be meaningful to social groupings). Given that nationalism has been a motivating force of politics since at least 1815, these scope conditions are not limiting.

A basic intuition behind the model - the ebb and flow of national identification as a function of changes in national status and national power - applies to A large array OF cases in both contemporary and historical settings. Four generic scenarios illustrate this variation. First is when fear of status loss leads to bellicosity, as in the examples from WWI with which we introduce this paper. In Russia's decision-making for war in 1914 we see clear evidence of our mechanism as well as a refutation of diversionary war theory. As Geyer $(1987,317)$ establishes, Russia's bellicosity was not an attempt to divert the public's 
attention from domestic failings; rather it reflected the desire to sustain the nationalist idea that was central to the elite's strategy for generating power internationally.

Second, military defeat can generate centrifugal pressures that many states have faced after defeat in war. ${ }^{9}$ The very situation leaders in Vienna and St Petersburg feared - the rise of local nationalism at the expense of identification with the larger empire - appeared with a vengeance after defeat in 1917-18. In more modern times, the resurgence of Islamism in Egypt was the direct result of, among other factors, losing the 1967 war. The Six Day War undermined the promise of nationalism throughout the Islamic world: "In confronting the humiliation, the deprivation, and the utter perplexity that followed what seemed an incomprehensible military defeat, an incisive moral verdict was discerned" (Gaffney 1992). Islamism gained ground at the expense of Egyptian nationalism (Ibrahim 1988); losing Arab Jerusalem "produced shock waves affecting both Arabs and non-Arab Muslims in engendering feelings of fear, insecurity and inferiority" (Dekmejian 1980, 8).

Needless to say, defeat can generate the material deprivation of both state and society, which can also feed centripetal forces. Hence, the third kind of scenario may be especially interesting: when unexpected performance against a much more powerful opponent allows national leaders to frame the loss as a victory. Here, the war's material effects run counter to the psychological mechanisms we highlight. Egypt after its defeat in the Suez war of 1956 is such an example. Although it can be coded as a military defeat for Egypt, the country lost no territory and stood up to "imperialists," forcing them to withdraw from Egypt, which allowed Nasser to claim it as a major victory. Standing up to Britain and causing British international status to decline in the process stoked Egyptian nationalism as it was perceived as a victory for Nasser, who became a pan-Arab hero after Suez. While Nasser made the cover of Time magazine, British Prime Minister Eden resigned soon thereafter.

Fourth is "nation building through war," in which military victory increases status and national identification. Material gains sometimes accompany victory in war; but extant

\footnotetext{
${ }^{9}$ The net effect of defeat is ambiguous in the model since the decline in national status might be offset by narrowing social distance after international war.
} 
approaches have focused almost exclusively on material sources of social identification and have assumed away the more intangible psychological dimensions that our model highlights. Though it has yet to be the subject of sustained research, abundant anecdotal evidence suggests that victory in the "Great Patriotic War" helped forge a Soviet identity after 1945 despite almost incalculable material losses. Although a Soviet "national" identity never supplanted already strong ethnic identities among many of the USSR's composite groups, allegiance to the state and feelings of pride among Soviet citizens were high after the victory and during the early Cold War days as the USSR scored diplomatic and other victories in its competition against the rival superpower.

Similarly, China's involvement in the Korean war helped "enhance communist control of China's state and society and to promote China's international prestige and influence" (Jian 1994, preface). Consensus opinion among China scholars is that "Fighting U.S.-backed United Nations troops to a standstill in Korea added enormously to the CCP's prestige" (Lieberthal 2004). The war "gave rise to a new mystique of Chinese endurance and heroism, which was elaborated in the People's Republic by an outpouring of literature, films, plays, and tales of the model soldier-heroes that reinforced the values of sacrifice and revolution" (Spence 1990, 505). Mao's revolutionary romanticism was supported by the constructed adversarial relationship with the United States (Zhang 253-254) and China's rising prestige fed a surge in national identification among large segments of the population during a difficult period with pockets of intense conflict and facilitated the state's propaganda machine as well as a series of coercive policies in the 1950s designed to unify the nation.

Although they may manifest themselves in many settings, the mechanisms we examine here are arguably clearest when a nucleus state attempts to enhance its size and power via inclusion of potential co-nationals outside its borders or when a nucleus state seeks to retain the allegiance of subjects with a potential exit option. As the fatal interaction between Serbia and the Austro-Hungarian empire in 1914 illustrates, this dynamic was strongly present in 19th and 20th century Europe, which frequently pitted dynamically rising national states 
against declining polyglot empires. Three major cases of nation-building through war stand out: Piedmont/Italy, Prussia/Germany and Serbia/Yugoslavia. In the mid 19th century, Piedmont fought wars against Austria to expel it from Italian affairs and exploited a reservoir of common in-group identity among Italians. After losing in its first effort, it then allied with France and Britain against Russia and Turkey in the Crimean War. As Cardoza (2000) observes, although the war "produced few immediate gains for the Piedmontese, their participation in the military operations and the Paris peace conference elevated the stature of the Savoyard state on the peninsula . . . [which] triggered a surge of pro-Piedmontese sentiment among both moderates and segments of the democratic left in other Italian states that found expression in the National Society, an organization launched in 1857 to promote Savoyard [Piedmont] leadership of the independent movement."

A half-century later, Serbia presented itself as the "south Slavic Piedmont." As Dedijer (1966, 76) observes "despite different cultural and religious influences, there existed a feeling of unity among South Slav peasant masses." Belgrade pursued an expansionist, nationalistic policy, enlarging its territory by $80 \%$ and population by $50 \%$ in the Balkan Wars in 1912 and 1913. Serbian leaders and intellectuals presented their nation as the potential nucleus of a much larger state that would bring together both Serbs and other south slavs, most of whom were Austro-Hungarian subjects. Authorities in Vienna attempted to counter by stoking particularistic and local identities in the lands they administered but, as noted, Serb battlefield success in the Balkan Wars "pitched Serbophilia to unprecedented euphoric heights" among many Croats in the Austro-Hungarian Empire (Banac 1984, 103). In part owing to its vigorous participation as an active belligerent in World War I, Serbia emerged as a dominant partner in the Kingdom of Serbs, Croats and Slovenes formed in 1918.

Though each case is complex and the relative significance of war to state-building varies, each featured a nucleus state that could plausibly appeal to a larger national identity. In each, elites in the nucleus stated were motivated to expand in part by realpolitik concerns of power and security. In each, the nucleus state engaged in war not just to expand territory 
but to gain status and thereby enhance the appeal of the larger national identity. In each, evidence suggests that military victory affected identity propensities among key populations and facilitated the construction of larger state institutions. This strategy would find its most famous expression in the person of Otto von Bismarck and the case of German unification.

\section{Focusing on the Franco-Prussian War}

Next, we adapt the model and apply it to a case where key parameters are salient and tractable empirically, the Franco-Prussian War of 1870-1. For subsequent modeling, $F$ and $G$ now stand for France and Germany, respectively. As in the baseline model, France is treated as a unified country, whereas Germany is divided along ethno-regional lines. Germany did not exist as a legal entity prior to 1871, or at the start of our model. Rather, in the events discussed here, "Germany" is represented by Prussia as the internationally recognized actor dominating the North German Confederation. As it faced France, Prussia was concerned about competition with other German states that remained independent with the main social division being between Northern German states led by Prussia on the one hand and Southern German states (Bavaria, Württemberg, Baden) on the other hand. People self-identifying as German were divided into two great powers (Prussia and Austria) and many smaller states. The strategic lead up to the 1870 war was shaped by Prussia's 1866 victory over Austria, which signaled Prussia's rise, excluded Vienna from German affairs and led to the annexation of several formerly independent German states into a Prussia-dominated entity called North German Confederation. Thus GROUPS $A$ and $B$ in the model now become Prussia/North Germany $(P)$ and South Germany $(S)$, respectively.

As leaders of Europe's perennially weakest great power, Prussian elites believed that their state needed to expand in order to ensure its security. Bismarck famously declared the need to expand Prussia's borders to encompass other German lands "not by speeches and majority resolutions... but by iron and blood" (Steinberg 2011, 180-1). The southern Germans' strategy, however, was to defend their sovereign autonomy or indeed increase it 
relative to Berlin. As the prime minister of one south German state put it, "Württemberg wants to remain Württemberg as long as it has the power" (Wawro, 24). France's strategic preoccupation was to maintain if not enhance its position of leadership in Europe and halt Prussia's rise (Eckerd, 276-303; Price 2001). A war between France and Prussia was expected to result in territorial divisions. A victorious France was expected to take German territory on the Rhine, as well as perhaps Belgium and Luxembourg, while Prussia was assumed to want sovereignty over the southern German states as well as German-speaking parts of France (Alsace). These territorial stakes are captured in French and German payoffs.

We consider the following variations to the baseline model: First, at the outset, regions $P$ and $S$ are independent states tied together via national ties in a loose political structure that might become unified. Prussia stands on its own, deciding whether to go to war with France while having an eye towards German unification. The outcome of a war with France could be decisive for unification. Second, we endogenize the probability of victory through arming, which explains why Prussia increased its arming relative to France in the 1860s and how it was able to mobilize support for war through nationalism. In a supplementary appendix, we also analyze a dynamic version of the static model that verifies all of the other reasons for war and allows for the likelihood of war to increase with a longer shadow of the future under an indefinite horizon.

In this model, the probability of winning $p$ is endogenous to unification because unification creates higher payoffs, so the leaders of Germany/Prussia decide to invest more in arming so as to capture these higher payoffs. The higher payoff under victory in the future - due to the expected higher status of Germany - increases arming now (before WAR) [DELETED WHAT USED TO FOLLOW IN THIS SENTENCE]. The choice to arm is made by the leaders of Prussia, who can be expected to have a forward-looking perspective. Once the decision to go to war has been made by their elites, individuals within Germany react to the new social environment and make their social identification decisions while taking the new strategic environment as given [CHANGED ORDERING IN THIS SENTENCE WITHOUT 
CHANGING A SINGLE WORD]. We start with the hypothetical case of Germany having no expectation of unification and then we delve into the case where unification is possible.

The two countries follow this sequence of moves:

1. France and Prussia simultaneously choose levels of arming $g_{f}$ and $g_{p}$, which determine the probabilities of winning for Prussia and France, respectively:

$$
p=\frac{g_{p}}{g_{p}+g_{f}} \text { and } 1-p=\frac{g_{f}}{g_{p}+g_{f}} \text { if } g_{p}+g_{f}>0 ; p=1-p=1 / 2 \text { if } g_{p}+g_{f}=0
$$

2. France and Prussia simultaneousy choose either War or Peace. If both choose Peace, then Peace prevails. If at least one country chooses War, then War takes place. Prussia wins with probability $p>0$ and France wins with probability $1-p$.

3. a. After Peace, victory for Prussia after War, or loss for Prussia after War, $P$ and $S$ decide whether to unify or not.

b. If there is a unified Germany, its elites play a modification of the game in (1); i.e., they decide whether to identify with their region or the nation.

Let the benefit to [DELETED "the median member of the"] Prussian elites from having part of the disputed territories be $\beta d$ (where $d$ is the benefit from all disputed territories and $\beta \in(0,1)$ is Prussia's share). ${ }^{10}$ France's Peace payoff would be $(1-\beta) d$ which represents the payoff from the disputed territories within existing borders. In the event of War, the winner would capture the loser's disputed territory and have a payoff from the disputed territories of $d .{ }^{11}$ As above, war would occur if one country were to choose War and each country would incur a cost $c>0$ in that period.

\footnotetext{
${ }^{10}$ An alternative specification would be to have the leaders maximize total income. Surprisingly, this would not affect the qualititative results we report and, if anything, would re-enforce them as the larger population of a unified Germany would be an additional and distinct incentive for Prussia to have war.

${ }^{11}$ Competition between France and other great European powers, including Prussia, was cast in terms of power. The economic output of specific regions was of interest as it translated into military advantage and political power. Napoleon III's main concern was to enhance France's position of leadership in Europe and preserve its influence over Southern German states so as to halt the growth of Prussia. The value of the disputed territory " $d$ " in the model is shorthand for all strategic interests that France had with respect to its adversary, including an interest in controlling territories that would help prevent German unification. We later show that in the presence of transfers/tribute, if France was not concerned about achieving a strategic advantage relative to Prussia (that is, if $d=0$ ) there would not be war.
} 
Next, however, we need to specify the payoffs and determine the equilibrium within Germany in stages $3 \mathrm{a}$ and $3 \mathrm{~b}$. We first suppose that the material payoffs of $P$ and $S$, other than what comes from disputed territories, are $v$ if Germany were not re-unified or if it reunified but $P$ or $S$ chose regional identification; the material payoff is $V\left(s^{i}\right)+s^{i}(i=\nu, p, l)$ if Germany were to be re-unified and $P$ and $S$ chose national identification $(G)$. Thus, the per-period payoffs of $P$ and $S$ in stage $3 \mathrm{~b}$ are essentially identical to those in (1):

$$
\begin{array}{ccc} 
& G & S \\
G & V\left(s^{i}\right)+s^{i}+d^{i} / 2, V\left(s^{i}\right)+s^{i}+d^{i} / 2 & v+s^{i}+d^{i} / 2, v+d^{i} / 2 \\
P & v+d^{i} / 2, v+s^{i}+d^{i} / 2 & v+d^{i} / 2, v+d^{i} / 2
\end{array}
$$

where $i=\nu, p, l$ and $d^{i}$ represents the payoffs that come from the disputed territories in each state of the world, with $d^{\nu}=d, d^{p}=\beta d$, and $d^{l}=0$. We have assumed that under unification, the per-capita payoffs are distributed equally between Prussian/Northern Germans $(P)$ and Southern Germans $(S)$ [DELETION HERE]. Moreover, since the values of $d^{i} / 2$ are the same in each cell, the equilibria we select are the same as in (1): Regional identification when $v>V\left(s^{i}\right)+s^{i}$ and national identification when $v<V\left(s^{i}\right)+s^{i}$.

In fact, consistent with the Franco-Prussia case evidence, we suppose in this section that $V\left(s^{\nu}\right)+s^{\nu}>v \geq \max \left\{V\left(s^{p}\right)+s^{p}, V\left(s^{l}\right)+s^{l}\right\}$ (corresponding to case II of the previous section) whereby national identification with Germany could occur only after victory in War.

Given that, the decision to unify in stage 3 a would depend on the expectation of social identification in stage 3b. In particular, in the case of victory in War, the per-period payoffs of the two sides ( $P$ is taken as the row player and $S$ as the column player) would be:

$$
\begin{array}{ccc} 
& \text { Unify } & \text { Not unify } \\
\text { Unify } & V\left(s^{\nu}\right)+s^{\nu}+d / 2, V\left(s^{\nu}\right)+s^{\nu}+d / 2 & v+s^{\nu}+d / 2, v+d / 2 \\
\text { Not unify } & v+s^{\nu}+d / 2, v+d / 2 & v+d / 2, v+d / 2
\end{array}
$$

where we have assumed (without loss of generality) that in the event of no unification Prussia would receive half of the benefit from the disputed territories. ${ }^{12}$ Since $V\left(s^{\nu}\right)+s^{\nu}>v$, Unification is the DOMINANT-STRATEGY equilibrium and we suppose from now on that Germany would unify after victory. Similarly, and without going through all the details,

\footnotetext{
${ }^{12}$ There is no loss of generality in the sense that other assumptions would also lead to unification.
} 
Germany would not unify in the cases of Peace and loss after War. The per-period payoffs of Prussia in the case of Peace would be $v+\beta d$ and in the case of loss after War would be just $v$.

The value of $V\left(s^{\nu}\right)+s^{\nu}$ in the case of a newly unified Germany (as opposed to the case of an already unified country) is that it would also gain full benefits of internal trade and economies of scope. For Prussian elites, including Bismarck, unification meant a stronger Prussia within a larger Germany that could compete with France and other great powers and ensure Prussia's long-term survival. ${ }^{13}$

\subsection{If Germany were to remain fragmented}

To show how the prospect of German unification changes arming, we first consider the benchmark counterfactual case of a fragmented Germany regardless of the war outcome. In the second War-or-Peace stage in which arming has already been determined and is "sunk" the payoffs under War $(w)$ and Peace $(p)$ are as follows:

$$
\begin{aligned}
& V_{F}^{w}=(1-p) d-c ; V_{P}^{w}=p d+v-c \\
& V_{F}^{p}=(1-\beta) d-\tau ; V_{P}^{p}=\beta d+v+\tau
\end{aligned}
$$

where $\tau$ denotes the size of the transfer from $F$ to $G$. In this case the total surplus under War $\left(V_{F}^{w}+V_{P}^{w}\right)$ equals $d+v-2 c$, which is strictly lower, because of positive War costs, than the total surplus under Peace $\left(V_{F}^{p}+V_{P}^{p}=d+v\right)$. Therefore, in the presence of transfers, there is always a way to have Peace. Arming, however, will still take place in order FOR EACH SIDE to maintain a better bargaining position in the presence of transfers. The transfer itself is determined by the bargaining process, which we suppose involves an "equal splitting

\footnotetext{
${ }^{13}$ Prussia's leading elites understood that economic development and military power were mutually reinforcing, and notwithstanding economic and military integration among independent German states, the realization of both objectives was limited in the absence of unification. See, especially, Carr 1991.
} 
of the surplus" between the two countries so that: ${ }^{14}$

$$
\begin{aligned}
V_{F}^{p}-V_{F}^{w} & =V_{P}^{p}-V_{P}^{f} \\
& \Longrightarrow \tau^{*}=(p-\beta) d \\
& =\left(\frac{g_{p}}{g_{p}+g_{f}}-\beta\right) d
\end{aligned}
$$

Note that the higher is Prussia's share of the disputed territory $(\beta)$, the lower is the implied transfer from France since Prussia is already sufficiently compensated from already holding the territory. Moreover, the implied transfer is higher the higher is Prussia's winning probability [DELETED REST OF SENTENCE HERE]. Since the transfer in the event of Peace depends on the probabilities of winning and the probabilities of winning depend on arming, it becomes evident why the transfer is a function of arming and why arming can be expected even when Peace is always expected.

By substituting the transfer $\tau^{*}$ into the Peace payoff functions, we eventually obtain what the two countries face in the first stage in which arming is chosen:

$$
\begin{aligned}
V_{F}^{p}\left(g_{p}, g_{f}\right) & =\frac{g_{f}}{g_{p}+g_{f}} d-g_{f} \\
V_{P}^{p}\left(g_{p}, g_{f}\right) & =\frac{g_{p}}{g_{p}+g_{f}} d+v-g_{p}
\end{aligned}
$$

The Nash equilibrium choices of arming are identical for the two countries in this case: ${ }^{15}$

$$
g_{f}^{*}=g_{p}^{*}=\frac{d}{4}
$$

The level of arming depends solely on the value of the disputed territory and none of the other variables. The two countries have equal probability of winning in War but PEACE IS ALWAYS AN equilibrium and the disputed territory is equally divided [DELETED "UNDER PEACE"; ALSO DELETED A FEW WORDS IN FOOTNOTE]. ${ }^{16}$

\footnotetext{
${ }^{14}$ Given that we have risk neutrality this is satisfied by any symmetric axiomatic bargaining solution, including the Nash and Kalai-Smorodinsky solutions. Moreover,equal division is the limit of noncooperative alternating offers games with an exogenous risk of breakdown (see Binmore, Rubinstein, and Wolinsky, 1986).

${ }^{15}$ For this to always be an equilibrium, we also have to check that it would not be in the interest of either country to deviate in the first stage with a different level of arming that would induce a higher payoff under War than under Peace. It can be easily checked that this is not the case, given that the equilibrium arming choices under Peace are also best responses to one another even under War.

${ }^{16}$ Again, as in previous cases, War is always in equilibrium since, if one side were to choose War, War is a
} 


\subsection{When Germany can unify}

Next, we return to the case in which victory after War would bring about German unification, whereas it would not do so under either Peace or after loss in a War. As discussed in the previous subsection, the payoff for Prussia after victory is now $V\left(s^{\nu}\right)+s^{\nu}+d / 2$, with the payoffs under the two other states remaining the same.

Then, in the second stage of the game, after arming has already taken place and the choice is between War and Peace, the payoffs for the two countries are:

$\bar{V}_{F}^{w}=(1-p) d-c ; \bar{V}_{P}^{w}=p\left(V\left(s^{\nu}\right)+s^{\nu}+d / 2\right)+(1-p) v-c=p\left(V\left(s^{\nu}\right)+s^{\nu}+d / 2-v\right)+v-c$

$\bar{V}_{F}^{p}=(1-\beta) d-t ; \bar{V}_{P}^{p}=\beta d+v+t$

While France's payoff functions remain the same, the payoff of Prussia under War receives the additional boost of $p\left(V\left(s^{\nu}\right)+s^{\nu}-v-d / 2\right)$ which reflects the extra economic benefit of German unification and the higher status and lower regional frictions that would follow a victory in War. Now the total surplus under War $\left(\bar{V}_{F}^{w}+\bar{V}_{P}^{w}\right)$ equals $d+v+p\left(V\left(s^{\nu}\right)+s^{\nu}-\right.$ $d / 2-v)-2 c$ and is no longer guaranteed to be higher than the total surplus under Peace $\left(\bar{V}_{F}^{p}+\bar{V}_{P}^{p}=d+v\right)$. In particular, if

$$
p\left(V\left(s^{\nu}\right)+s^{\nu}-d / 2-v\right)>2 c
$$

(that is, if the expected extra benefits of War to Prussia are greater than the total war costs

of the two countries), then no transfer from France to Prussia could prevent War in the second stage of War and Peace.

\subsubsection{The case of Peace}

This case prevails when the costs of War are at least as high as the expected extra benefits of War to Prussia ((11) is not satisfied). Again, we suppose that at the second stage bargaining involves splitting the surplus of the difference between Peace and War, with implied transfer best response for the other side. Since in this subsection Peace is always Pareto optimal we concentrate on the case of Peace as an equilibrium. 
from France to Prussia shown below:

$$
\begin{aligned}
\bar{V}_{F}^{p}-\bar{V}_{F}^{w} & =\bar{V}_{P}^{p}-\bar{V}_{P}^{w} \\
& \Longrightarrow \tau^{p}=(p-\beta) d+\frac{p}{2}\left(V\left(s^{\nu}\right)+s^{\nu}-d / 2-v\right) \\
& =\left(\frac{g_{p}}{g_{p}+g_{f}}-\beta\right) d+\frac{g_{p}}{2\left(g_{p}+g_{f}\right)}\left(V\left(s^{\nu}\right)+s^{\nu}-d / 2-v\right)
\end{aligned}
$$

The implied transfer from France to Prussia for any given choice of arming includes an additional term to that of $\tau^{*}$ that is positive (and therefore implies a greater transfer from France to Prussia). That term reflects Prussia's expected extra benefit of War. Letting for notational simplicity $D \equiv V\left(s^{\nu}\right)+s^{\nu}+d / 2-v(>d)$, the implied Peace payoff functions with endogenous arming then are:

$$
\begin{aligned}
\bar{V}_{F}^{p}\left(g_{p}, g_{f}\right) & =\frac{g_{f}}{g_{p}+g_{f}} d-g_{f} \\
\bar{V}_{P}^{p}\left(g_{p}, g_{f}\right) & =\frac{g_{p}}{g_{p}+g_{f}} D+v-g_{p}
\end{aligned}
$$

When $D>d$, for any given level of arming, Prussia receives a higher payoff than France. This outcome reflects, again, Prussia's better bargaining position that stems from its extra benefit of War. As a result, Prussia arms more than France in equilibrium:

$$
\begin{aligned}
& \overline{g_{f}}=\frac{d^{2} D}{(d+D)^{2}} \\
& \overline{g_{p}}=\frac{d D^{2}}{(d+D)^{2}}
\end{aligned}
$$

The level of Prussia's arming relative to that of France depends on the size of $D$ relative to $d$ or how high are the extra economic benefits of German unification and its status benefits relative to the value of the disputed territories. ${ }^{17}$

\subsubsection{The case of War}

This case occurs when the expected extra benefits of War to Prussia are higher than the costs of War ((11) is satisfied). The payoff functions for War are:

\footnotetext{
${ }^{17}$ It can also be shown that $\overline{g_{p}}>g_{p}^{*}$ and $\overline{g_{f}}<g_{f}^{*}$.
} 


$$
\begin{aligned}
\bar{V}_{F}^{w}\left(g_{p}, g_{f}\right) & =\frac{g_{f}}{g_{p}+g_{f}} d-g_{f}-c \\
\bar{V}_{P}^{w}\left(g_{p}, g_{f}\right) & =\frac{g_{p}}{g_{p}+g_{f}} D+v-g_{p}-c
\end{aligned}
$$

These payoff functions differ from those under Peace only in terms of the (constant) cost of War $c$. The incentives of arming persist, yielding equilibrium arming that is the same as that under Peace $\left(\overline{g_{f}}\right.$ and $\left.\overline{g_{p}}\right)$. The ensuing winning probability for Prussia is:

$$
\bar{p}=\frac{\overline{g_{f}}}{\overline{g_{f}}+\overline{g p}}=\frac{D}{d+D}
$$

which is obviously greater than $1 / 2$, and the higher it is, the higher are the extra benefits of War that stem from German unification. Given that the condition for War in (11) involves the probability of winning $p$, and here we have endogenized the winning probability, by substitution of $\bar{p}$ in that condition, we can obtain the following condition for War in terms of the underlying variables:

$$
\frac{\left[2\left(V\left(s^{\nu}\right)+s^{\nu}-v\right)+d\right]\left[2\left(V\left(s^{\nu}\right)+s^{\nu}-v\right)-d\right]}{2\left(V\left(s^{\nu}\right)+s^{\nu}-V\right)+3 d}>4 c
$$

We summarize the implications of this inequality as well as the results about arming in the following Proposition.

Proposition 2 Suppose arming and the winning probabilities are endogenously determined when there is the prospect of German unification after victory in War.

(i) Then, the higher are the benefits to German unification, regardless of whether War or Peace prevails the higher is Prussia's arming relative to France and the higher is Prussia's winning probability.

(ii) War is more likely, the lower are the costs of War (c); the higher are the economic benefits from German unification $\left(V\left(s^{\nu}\right)-v\right)$, FOR A FIXED $\left.s^{V}\right)$; the higher is the status after victory $\left(\sigma^{v}\right)$ and the lower are the distance costs after victory in $\operatorname{War}\left(\Delta^{v}\right)$.

The first part of the Proposition has already been shown. The second part is shown in the Appendix. 


\section{Case Illustration: The Franco-Prussian War and Ger- man Unification}

The model we presented helps illuminate connections between internal and external conflict via the mechanism of social identification. The prospects of higher payoffs due to unification and the fact that these payoffs are contingent on war outcomes, make the state more warprone than it otherwise might be. An analytic narrative of the Franco-Prussian war illustrates the value of the model in three ways. First, we show that our theoretical predictions are consistent with the evidence concerning strategic choices and incentives in the lead-up to the war. Second, our expectations about the effects of military victory on nation-building are borne out by the historiography of the case. Third, the model captures factors central to the explanation of that great power war that are missed by extant approaches.

\subsection{Status, Social Identity and the Effects of Intra-German War}

In the years before 1870, evidence available to Bismarck and other top Prussian leaders indicated that unification would not occur without the nationalist upsurge that a victory over France would produce. To enhance its power Prussia had three strategies: conquer other German states by force; use subtler incentives to draw the southern Germans into the fold; or increase the attractiveness to Germans of identifying with a German Reich that did not compromise Prussian identity by enhancing Germany's inter-state status. Ever the pragmatist, Bismarck tried all three. After defeating Austria, Prussia conquered and annexed several northern German states in 1866, and then used war booty to enhance material incentives for unity. Ethnic conflict makes ethnic identities more salient and fighting German-

led Austria and its German allies (Bavaria, Württemberg, Saxony, Hanover, Baden, and several smaller German states) generated a backlash of hostility toward Prussia and a major setback for the cause of unification. Bismarck then tried using economic inducements via the customs union, but southern German particularists used the opportunities to increase their sway, producing major defeats for pro-unification parties at the polls (Pflantze 1990, 
392-5). After Southern voters elected anti-unionist conservative candidates in the Customs Union elections of 1868, a Swabian newspaper proclaimed the vote as "the protest of South Germany against Prussification." Bismarck himself took the result as a clear signal "that the south wishes to have no further connection with the north beyond customs treaties and the alliance treaties." 18 Off the record he agreed with his envoy to Munich that "German unity is likely to be fostered by violent events," but stressed that "it is self-evident ... that Germany at this moment is not a ripe fruit...."19

The strategies of conquest and subtle inducement failed. As Carr (1991, 172) writes, "on the eve of the Franco-Prussian war anti-Prussian sentiment in the south was... growing stronger, not weaker." The local parliamentary elections of 1869 ended up with the sound victory of particularist parties. In Württemberg, particularists won a majority and, encouraged by a petition endorsed by 150,000 signatories, pressured the government in freeing Swabia from the "slavery of the barracks" by cutting military expenditures and into reducing the length of military service, against Prussia's wishes. In Bavaria, the Patriotic Party won a majority and passed a no-confidence vote on the Prussian-leaning prime-minister Prince Hohenlohe to replace him with a pro-Austrian cabinet (Pflantze 1990, 405-8).

In sum, Prussia's status gains at Austria's expense were not enough to offset the widening social distance that this intra-German war created. There was thus a weakening of national (German) identity, while the expected payoffs to unification persisted and continued to motivate Prussian elites to pursue that goal.

\subsection{Status, Social Identity and War with France}

Bismarck's deteriorating position on the intra-German chessboard led him to pursue an aggressive strategy to gain prestige at the expense of France, even at risk of war. As he put it to King Wilhelm "every recognizable attempt of Prussia to determine the decision of

\footnotetext{
18 "Bismarck in conversation to Suckow, Minister of War in Wurttemberg, 11 May 1868," in Böhme (1971, 200-1).

${ }^{19}$ The letter goes on to note that confrontations with France led to rising national feelings in the 1840s. Doc. No. 63 (Bismarck to von Werthern) in Becker 2003. This is consistent with the model, as discussed in section 4.4.2, where unification does not occur without a victory over France.
} 
the south-German princes, by pressure or agitation will have as its consequence the opposite of the result sought" and would have strengthened rather than weakened the ties between Bavaria and Wurttemberg and Paris and Vienna (Wetzel 2001 63-71; Böhme 1971, 2034). The strategy of inducement necessarily involved gaining prestige at France's expense, which Bismarck ultimately sought to accomplish by encouraging the candidacy of a Prussian Hohenzollern prince for the newly available throne of Spain (Steefel, 1962, 56-88; Wetzel, 2001, 77-88; Steinberg, 2011 chap. 5). As the south German states' major remaining great power patron, France was an obstacle to unification and, by presenting it with a setback, Prussia would undermine the confidence of Munich and Stuttgart in French commitments to their independence while raising the prestige of Berlin among southern Germans.

Bismarck set forth his reasoning in a letter to King Wilhelm in March 1870: "it is desirable for Germany to have on the far side of France a country on whose sympathy she can rely and with whose susceptibilities France would be obliged to reckon... The repute of the Hohenzollern dynasty, the justifiable pride with which not only Prussia regards its Royal House but Germany too - she tends more and more to glory in that name as a common national possession, a symbol of German fame and German prestige abroad; all this forms an important element in political self-confidence, the fostering and strengthening of which would be of benefit to nationalist feeling in general" (Böhme 1971, 218-9). The evidence suggests that Bismarck's preferences were shared widely within Prussia's ruling elite.

Consistent with Proposition 2(i), the high expected benefits of German unification led Prussia to arm proportionally more than France. Chief of Staff Moltke and War Minister Roon had been assiduously organizing the army to prepare for such a war since 1866 (Wawro 2003, Howard 1962). In each preceding crisis Bismarck favored negotiated settlements with France, brushing aside Moltke's concern that France might finally reform its military establishment and present a tougher challenge. He only came to the tough line against France when other routes to unity seemed to be running into a dead end.

Bismarck's plan to present Paris with a fait accompli was compromised when the Ho- 
henzollern candidacy became public information, sparking an immediate French demand for its revocation. In the ensuing complex diplomacy numerous compromises were negotiated that would have saved both French and German face. Bismarck worked feverishly to scuttle such deals, making sure that the crisis was framed as a status contest between France and Prussia. "Bismarck... set sail on a collision course with the intent of provoking either war or a French diplomatic humiliation" (Pflantze 1990, 462).

In Paris, Emperor Napoleon III and his foreign minister Antoine de Gramont also faced a choice. Key here is that they had the same preference ordering as prevailed in Berlin: better war than a mutually face-saving deal that preserved the status quo. The French were determined "to turn the affair into a public humiliation of Prussia" (Price 2001, 427). A key desideratum was to deal a blow to Prussia's rise by thwarting its futher expansion at the expense of the southern German states (Wawro 2003, 9-10; Echard 1983; Price 2001). In the view of leading French decision makers - shared in other European capitals - France's prestige relative to Prussia had declined after many diplomatic and military setbacks, notably the smashing of France's Austrian ally and then Bismarck's brusque and ultimately public rejection of Napoleon's attempt to gain compensation by acquiring Luxembourg (Case 1954, chapter 9). The French emperor's advisor warned that "Grandeur is relative" (Wawro 2003, 17) and France was not in a position to risk further decline relative to Prussia. Eugene Rouher, French minister of state, had a clear strategy in mind: "Smash Prussia and take the Rhine... By 'the Rhine,' Rouher meant Prussia's western cities: Cologne, Dusseldorf, and the Westphalian Ruhrgebiet around Essen, Dortmund, and Bochum" (Wawro 2003, 17). Even the prime minister, Ollivier, a socialist originally opposed to Napoleon's imperialism, ultimately rejected a face-saving solution as unbefitting France's "honor" (Wetzel 2001, 145). As the crisis gathered steam, evidence poured into the government of public support for a hard line against Prussia (Case 1954, chapter 10). Thus, our proposition 2(ii) illustrates the motives for escalation to war both within Germany and France.

Germany's domestic conflict played into French calculations. Case (1954) shows evidence 
of concern in Paris that backing down to Prussia would likely pull the rug out from under pro-France and anti-Prussian southern Germans. Should France defeat Prussia militarily, Prussian expansion in Germany would not only be halted but probably reversed as recently annexed states like Hanover would seek greater autonomy. To be sure, should Prussia win, a consolidated Germany was virtually certain, but decision makers in Paris still gave France a clear edge (Carr 1991, Howard 1962, Wawro 2003). Pre-war French assessments projected a groundswell of support in non-Prussian Germany (Price 2001, 440). As the Grand Duke of Hesse assured one French general "the slightest [French] success will determine all the states of South Germany to march with you" (Howard 1962, 45).

\subsection{The War's Effects on Social Identification in Germany}

War with France generated two main psychological effects for German unity: a rally-aroundthe-flag effect against a common external foe, and the increased salience of the new Prussiansponsored German identity in light of its heightened inter-state prestige. The rally-around the flag effect is notable before and in the early stages of the war, when its outcome was unknown, and it facilitated large-scale mobilization and arming that gave Prussia an edge it would otherwise not have had. The status effect was crucial for unification and becomes clearer as the immediate threat from France recedes and Germany's augmented international status becomes evident after a series of decisive victories.

Evidence abounds of widespread popular support for Prussia against France, such that the governments concerned had essentially no choice but to honor their treaty obligations to fight with Prussia or risk popular revolt (Böhme 1971, 231-2; Wetzel 2001, 155-8). There were still hold-outs, however, especially in Catholic-heavy areas. Thus, in Bavaria peasants cut their corn green so it would not be trampled by Prussian troops, and expressions of sympathy toward France could be heard from parishes to the parliament, where many members of the winning party actually favored neutrality (the vote on the military budget which was the best indication of support for Prussia won by 100 to 47 votes). Support for France could 
also be detected in recently Prussian-occupied areas such as Hanover and Mainz, where the population was "waiting for the French as if for the Redeemer" (Howard 1962, 59-60). But, on the whole, the Southern states' populations supported the war due to genuine nationalist sentiment. The Bavarian People Party thus had to bow to popular demands and demonstrations of nationalist fervor occurred in both Bavaria and Wurttemberg (Howard 1962, 59-60; Fink 2005, 155-71; Pflantze 1990, 491). According to one historian, "Though the princes, soldiers, and bureaucrats of south Germany had a vested interest in remaining outside of Prussia, millions of south German citizens wanted a nation-state, which was something only Prussia could deliver" (Wawro 2003, 24).

The effects of military success can be seen more clearly in the decision to create the German Reich. The decision was taken in the aftermath of the crushing victory at Sedan, which determined the outcome of the war. The minister president of the North German Confederation Rudolf von Delbrück reports on a conversation on September 7 with King Wilhelm and Bismarck that the creation of a united Germany was now seen as an "easy task" after eight victorious battles in which the German forces had fought together. As Delbrück reports, the feeling was that "self-confidence, heightened by great deeds and great success, outweighed the army's feeling for the individual states whose contingents composed it. This self-confidence overshadows or overcomes every other feeling. He who did not consider feeling for Bavaria or for Württemberg as impermissible now and would not hear of ignoring or overcoming state particularism, ran the danger of passing for a dull or mean man, if not for something worse" (Böhme 1971, 237-78). This was an argument that would have been anathema for Bavarians and Swabians at the start of the year 1870, and that Bismarck could not have voiced even at the beginning of the hostilities with France. To the extent that it could be stated outright, it was only due to the changed circumstances created by military success.

Bismarck eschewed any hint of coercion versus the southern German states, which now 
lacked any great power protector. ${ }^{20}$ There was no reason not to offer generous terms of autonomy, since as he put it: "the Rubicon has anyhow been crossed." To preserve the Prussian identity he treasured, as well as to smooth the path for southern German entry into the new Reich, Bismarck did not seek a monolithic national state similar to France; instead, as he put it, he preferred to "absorb... German nationalities without nullifying them" (Schmidt 1985, 41).

What we observe is increased salience of the German identity even as individuals retained their local identities (see, e.g., Confino 1997; Applegate 1990). As Green (2005, 132) argues, the German nation was understood as "a composite nation, made up of several sub-national groups." Individuals retained some loyalty to different identities each nested within a more encompassing one (cf. Wimmer 2008). But in the period that we are analyzing, German identity assumed a more concrete form, defined by political developments on the ground, just as constructivist theorists would predict. Thus, the observed shift in social identification was toward the Prussia-dominated German Reich Bismarck had been constructing ever since the victory over Denmark in 1864. The two identities were no longer seen as contradictory. To quote Hardtwig (Weichlei 2000, 167): "the rivalry between the nation and states diminished in significance. It seemed to be more important that national consciousness came to be based on particularistic identities; the supportive aspect overshadowed the rivalry." This cognitive shift is consistent with the re-alignment of social identification due to war in the model. As strong as local identities remained in Baden, Saxony, Württemberg and Bavaria, the victory over France occasioned a major shift from fighting Prussia in 1866 to voting in anti-Prussian majorities in 1870 to celebrating entry into a Prussia-dominated Germany in 1871.

Prussia did not even have the chance to begin in earnest discussions for unification

\footnotetext{
${ }^{20}$ This is consistent with Mylonas's nation-building theory, which predicts that the state will pursue accommodative policies toward non-core groups (minorities that are not considered part of the nation) if they do not have external backers that would turn them into fifth columns. Policies of assimilation or expulsion will be used where unassimilated groups pose a security threat to the state. In our case, South German states are not the typical "non-core" group since they did share a German national identity - albeit a weak one until the war with France. Nonetheless, our theory is consistent with the approach suggested by Mylonas and our model could be usefully extended to formally consider the role of external intervention.
} 
before the southern states approached Berlin of their own initiative. Before Delbrück had a chance to call in session the Zollparlament, Bavaria preempted the action by suggesting a "constitutional" or even "diplomatic" alliance between the North German Confederation and the southern states. This concession represented precisely the outcome that had been rejected tooth and nail in the 1868 vote. The victory at Sedan and the nationalist effervescence that it generated sealed the Bavarian decision. And the newfound power of the national identity supported a wave of state capacity building, as the North German Consitution was extended over the new German Reich and a vast array of new state institututions was established, from the central bank and national currency to social welfare and education. Most notable was the unification of German laws, which the governments of Bavaria, Wurtemberg and other states initially resisted. But, Eyck $(1950,197)$ observes, "the national movement swept these obstacles away" and paved the way for investments in state capacity.

\section{Conclusion}

France and Prussia were bargaining in the shadow of shifting power under anarchy, a setting extant theories predict would raise the specter of war. But the standard theoretical toolkit misses critical determinants of actors' expectations of future power shifts and thus cannot explain their strategic choices. By reintegrating the insights of the real Realpolitik - the classical theory of statecraft - our theory fills major gaps in rationalist theories of interstate war in a way that resonates powerfully with historical evidence. Expectations about what would influence the social identification of southern Germans explain why an arcane monarchical succession problem was deliberately framed as a zero-sum status contest between two great powers who preferred to fight a war rather than lose prestige. Key elements of this case are missed by the most closely related existing approaches.

First, modern realist theory misses the intimate connection between the politics of social identity and nationalism, on the one hand, and the power politics of security and balancing, on the other hand. John Mearsheimer $(2006,78)$ cites the Franco-Prussian war to say that 
"[S]ecurity is not always the principle [SHOULD THIS BE "PRINCIPAL"?] driving force behind a state's decision for war... Ideology and economic considerations are sometimes paramount." But our model shows that nationalism is fused with power politics. Prussian Realpolitik was not reducible to a simple strategy of gathering up German lands by force. Bismarck came to appreciate the power of social identity and decided to pursue "unification by consensus" (Pflantze 1990, 369) precisely because security was paramount. When soft strategies of inducement failed, Bismarck turned to the inter-state level, where winning status at France's expense through victorious war delivered what seemed unattainable otherwise. Appreciating this dynamic, French leaders faced potent incentives to accept the challenge and face Prussia down.

Second, the diversionary war hypothesis is too narrowly focused on the domestic level and misses the Realpolitik pursuit of power in a competitive inter-state environment. In most renderings (see, e.g., Snyder 1991, Snyder and Mansfield 2005) foreign belligerence is a suboptimal response to a domestic crisis. That view does not capture the forward- and outward-looking essence of Bismarck's grand strategy. To be sure, the rally-around-the-flag effect that is central to diversionary war did figure in this case, but it was not enough. The effects of victory-related status gains on social identification are absent from diversionary war theory, as is the importance of investments in state capacity to sustain gains in national identification due to a rise in national status.

Third, leaders' concern for status or prestige was not a reflection of their own psychological needs (cf. Lebow 2008); a consequence of 'irrationality' or a 'myth' covering for other domestic pathologies (e.g. Snyder 1991); or a stand-in for reputation (Dafoe, Huth and Renshon, 2014). To an important degree, the focus on relative status reflected an assessment of its implication for domestic social identity and subsequent state power.

Fourth, the social identity shift produced by war might not have been long-lived had it not been for the underlying cultural bonds tying Germans together, which in turn explained their investments in state capacity in the aftermath of victory. Bismarck's decision to use the gains 
from war to support internal conflict-reduction institutions would help ensure the continued cooperation of southern elites, shoring up German nationalism. The case thus illustrates the three-way interaction between victory in foreign war, nationalism, and state-building that the model highlights. The idea of Germany pre-existed the interactions we model here and without it, strategic elites would not have been able to generate the nationalist sentiment that ultimately unified the German state.

Our theory builds on earlier second-image-reversed approaches by considering the effect of structural factors on institutional and individual-level variables. However, unlike prior approaches, we show that key concepts in structural theories -specifically, state power and balancing- cannot be fully understood without reference to individual-level psychological mechanisms. We also go beyond other rational choice approaches to domestic ethnic conflict by considering the implications of inter-state competition and modeling forward-looking elites who are strategic, but also constrained in their ability to mobilize their populations by those populations' social preferences.

The theory captures insights on unification nationalism (Hechter 2001) but should also apply to any setting in which individual loyalties are divided between parochial identities and the nation, though not all wars can be expected to produce the nation-building effect we describe. The war must be understood as pitting the nation against a key adversary that is more culturally distant from the nation's constituent social groups than are those social groups distant from each other; and victory must raise the nation's status considerably, reordering a social hierarchy in ways that affect both elites' and individuals' material payoffs. Nationalism is not entirely the consequence of victory in war and our theory is compatible with a framework in which a national identity is already shared among the population due to exogenous factors. In the case of Germany, a national ideal pre-existed the victory over France and most Germans perceived their regional identities as nested within their national identity. Victory in war led them to re-orient themselves toward the nation at the expense of the regions, but it did not destroy regional identification. The tradeoffs between parochial 
and super-ordinal identities that Germans faced are similar to tradeoffs that likely arose across empires in the early nationalist era as well as multiethnic states in later periods. Our theory's explanatory power in those other settings should be considerable, unless national identification is so strong as to be nearly inelastic to large changes in social status and to events that affect the salience of sub-national cleavages. Conversely, if national identity is weak and ethnic identity strong, possibly due to a history of prior internal conflict, even large gains in national status might be insufficient to induce national identification and secessionism will be common.

To be sure, we have identified only one of several possible mechanisms of nation-building. Other mechanisms may be more important in different contexts. A fruitful extension of our model would be to consider the implications of external meddling in the nation-building process. As others have argued (e.g. Mylonas 2013), national integration can be the result of ethnic cleansing of groups with foreign backers or assimilation of groups with no support from cross-border co-ethnics. Moreover, the relative fixity of national identity and the extent to which it responds to fluctuations in status would be relevant in determining the empirical applicability of our mechanism relative to other explanations. In the context of pre-WWI politics, when national prestige preoccupied leaders and common citizens alike and when national identification enhanced effective power projection in war, our model suggests that state power could not be understood without reference to the process of social identification that shifted individuals' allegiances from parochial to national identities. War caused a shift toward nationalism that was sustained by investments in state institutions designed to keep the nation together. The state built its capacity on a pre-existing sense of common national identity and, in turn, state institutions helped shore up that identity by reducing the costs of domestic conflict. We have illustrated our theory's compatibility with an important case of great power war and expect that it should be applicable to a wide range of empirical settings. Exploring the fit of the theory to different cases will be profitable in refining our understanding of interstate war, state-building, and nation-building - three processes that 
our model ties together. The scope for applying the mechanisms we highlight to explain state behavior in the early nationalist period is considerable. To paraphrase Tilly, war did not only make the state - it also helped make the nation. 


\section{APPENDIX}

\section{Foundations of the Domestic Interactions Model}

In this Appendix we develop the model underlying the matrix game in (1) and show how the material payoffs $v$ and $V(s)$ are derived. The sequence of moves is the following:

1. Each group decides whether to identify nationally $(N)$ or ethnically $(A, B)$.

2. Given identities from stage 1, each group makes a choice about how much to contribute to state capacity (denoted by $I_{A}$ and $I_{B}$ ).

3. Given identities and state capacity from stages 1 and 2, the two groups make costly conflict efforts $\left(e_{A}\right.$ and $\left.e_{B}\right)$ and the payoffs of each group are determined.

Let $Y$ denote the total "gross" available material resources or income in the country. In stage 3 of the game described above, each group holds the same fraction, denoted by $\kappa / 2$, of this income securely but the fraction $1-\kappa$ is contested by the two groups (obviously, $\kappa \in[0,1])$. We identify $\kappa$ as state capacity, which as discussed in the main text captures the strength of institutions and the ability of the state to mediate in disputes between the two groups. The groups' costly efforts to capture the contested part of income, $e_{A}$ and $e_{B}$, determime its distribution. The share of the contested income that group $A$ receives as a function of the efforts of both groups is denoted by $q\left(e_{A}, e_{B}\right)$ whereas the share received by group $B$ is the remainder $1-q\left(e_{A}, e_{B}\right)$. We assume $q\left(e_{A}, e_{B}\right)$ to be increasing and strictly concave in $e_{A}$, decreasing in $e_{B}$, and symmetric in the sense that $q\left(e_{B}, e_{A}\right)=1-q\left(e_{A}, e_{B}\right)$ so that $q(e, e)=1 / 2$ for all $e \geq 0 .{ }^{21}$ For any combination of efforts and contested fraction $1-\kappa$, the material payoffs of the two groups are as follows:

$$
\begin{aligned}
& \pi_{A}^{m}\left(e_{A}, e_{B} ; \kappa\right)=q\left(e_{A}, e_{B}\right)(1-\kappa) Y+\frac{\kappa}{2} Y-e_{A} \\
& \pi_{B}^{m}\left(e_{A}, e_{B} ; \kappa\right)=\left[1-q\left(e_{A}, e_{B}\right)\right](1-\kappa) Y+\frac{\kappa}{2} Y-e_{B}
\end{aligned}
$$

\footnotetext{
${ }^{21}$ This is a deterministic version of "contest success functions" or "contest functions" that have been employed extensively in models of conflict (an early example is Hirshleifer, 1989, and Jia and Skaperdas, 2012, provide an overview). Below we use further assumptions to simplify our analysis and we use a specific functional form for determining arming between France and Prussia.
} 
Given these payoff functions and the assumptions on $q\left(e_{A}, e_{B}\right)$, this game has a unique and symmetric pure-strategy equilibrium in which each group chooses effort, denoted by $e((1-\kappa) Y)$, where these efforts are increasing in the share of contested income (so that the higher is the fraction of income that is contested, the higher is the equilibrium effort of each side). Thus, the material payoffs of the two groups become:

$$
\pi_{A}^{m}(\kappa)=\pi_{B}^{m}(\kappa)=\frac{1}{2}(1-\kappa) Y+\frac{\kappa}{2} Y-e((1-\kappa) Y)=\frac{1}{2} Y-e((1-\kappa) Y)=\gamma(\kappa) Y
$$

where, under certain reasonable assumptions on $q\left(e_{A}, e_{B}\right),{ }^{22}$ [ADDED TEXT TO FOOTNOTE] $\gamma(\kappa)(<1 / 2)$ is the fraction of total "gross" income that each group receives as material payoff "net" of the costs of conflict. The higher is the fraction of the secure resource $\kappa$, the higher is the share $\gamma(\kappa)$ of total "gross" income that each group receives as part of its material payoffs because each party will expend less effort to capture a lower share of contested income.

State capacity $\kappa$ depends on inherited investments and other factors (denoted by $I_{-}$) as well as investments by the two groups, $I_{A}$ and $I_{B}$, in stage 2 of our game. We denote the relevant function as $\kappa\left(I_{A}+I_{B}+I_{-}\right)$, which is increasing in its argument and strictly concave. It follows that the equilibrium material payoffs in (13) that take account of conflict efforts and, in turn, depend on state capacity can change as a result of the investments in state capacity. The payoffs that take into account these investments in stage 2 are:

$$
\begin{aligned}
& \pi_{A}^{m}\left(\kappa\left(I_{A}+I_{B}+I_{-}\right)\right)=\gamma\left(\kappa\left(I_{A}+I_{B}+I_{-}\right)\right) Y-I_{A} \\
& \pi_{B}^{m}\left(\kappa\left(I_{A}+I_{B}+I_{-}\right)\right)=\gamma\left(\kappa\left(I_{A}+I_{B}+I_{-}\right)\right) Y-I_{B}
\end{aligned}
$$

For any given level of "gross" income $Y$, there could be a wide range of investments in state capacity. The low end in that range is given by the Nash equilibrium of the game with

\footnotetext{
${ }^{22} \mathrm{~A}$ condition for this result is that the shares for the two groups are functions of the ratio of efforts (Hirshleifer, 1989). For example, for the case of $q\left(e_{A}, e_{B}\right)=\frac{e_{A}}{e_{A}+e_{B}}\left(=\frac{\frac{e_{A}}{e_{B}}}{\frac{e_{A}}{e_{B}}+1}\right)$, we have $e((1-\kappa) Y)=\frac{(1-k)}{4} Y$ and $\gamma(\kappa)=\frac{1+\kappa}{4}$.

What is sufficient for the results here for $\gamma(\kappa)$ is that it is increasing and concave in $\kappa$, and independent of $Y$. However, even dependence on $Y$ could be handled but with some additional complication in the argument.
} 
payoff functions in (14). We denote that by $\kappa_{l}(Y)$. At the high end of the range are the investment choices that would maximize the sum of payoffs (or, total welfare) in (14); we denote that level of state capacity by $\kappa_{h}(Y)$. The difference between $\kappa_{h}(Y)$ and $\kappa_{l}(Y)$ reflects the difference between collectively rational choices and individually rational ones. We next show how $\kappa_{h}(Y)$ and $\kappa_{l}(Y)$ are derived.

First, we show how $\kappa_{l}(Y)$ results from the Nash equilibrium of the game with the payoff functions in (14) with strategies $I_{A}$ and $I_{B}$ for the two groups. We assume that all the relevant functions are differentiable. Let $I_{l} \equiv I_{A l}+I_{B l}+I_{-}$be the total investment in state capacity associated with the Nash equilibrium. We suppose, solely for convenience, that $I_{l} \geq I_{-}$(or that the inherited level of investment in state capacity is not higher than that implied by the Nash equilibrium choices) and that $I_{l}>0$ (guaranteed, for example, by an Inada-type condition that $\left.\kappa^{\prime}(0)=\infty\right)$. Then, the equilibrium choices must satisfy:

$$
\begin{aligned}
& \frac{\partial \pi_{A}^{m}\left(\kappa\left(I_{l}\right)\right)}{\partial I_{A}}=\gamma^{\prime}\left(\kappa\left(I_{l}\right)\right) \kappa^{\prime}\left(I_{l}\right) Y-1=0 \\
& \frac{\partial \pi_{B}^{m}\left(\kappa\left(I_{l}\right)\right)}{\partial I_{B}}=\gamma^{\prime}\left(\kappa\left(I_{l}\right)\right) \kappa^{\prime}\left(I_{l}\right) Y-1=0
\end{aligned}
$$

Note that the two equations are the same, implying that there is no uniquely determined pair of $I_{A l}$ and $I_{B l}$, even though the total equilibrium investment, $I_{l}$, is uniquely determined. Here we are assuming that the two groups undertake the same levels of investment so that $I_{A l}=I_{B l}=\left(I_{l}-I_{-}\right) / 2$. Furthermore, note how an increase in $Y$ would increase the first term of either first-order condition and, given the properties of $\gamma(\cdot)$ and $\kappa(\cdot)$, lead to an increase in $I_{l}$ and, therefore, an increase in state capacity so that $\kappa_{l}^{\prime}(Y)>0$.

Second, we derive the collectively optimal choice of state capacity $\kappa_{h}(Y)$. It is derived by choosing the level of investment that maximizes the sum of the payoffs in (14):

$$
\begin{aligned}
I_{h} & \equiv I_{A h}+I_{B h}+I_{-}=\arg \max _{I_{A}, I_{B}} \pi_{A}^{m}\left(\kappa\left(I_{A}+I_{B}+I_{-}\right)\right)+\pi_{A}^{m}\left(\kappa\left(I_{A}+I_{B}+I_{-}\right)\right) \\
& =\arg \max _{I_{A}+I_{B}} 2 \gamma\left(\kappa\left(I_{A}+I_{B}+I_{-}\right)\right) Y-I_{A}-I_{B}
\end{aligned}
$$

The corresonding first-order condition is

$$
2 \gamma^{\prime}\left(\kappa\left(I_{h}\right)\right) \kappa^{\prime}\left(I_{h}\right) Y-1=0
$$


This condition differs from the one for Nash equilibrium in that its first term is multiplied by 2 , reflecting the fact that the marginal benefit of investment takes account the total material welfare of the two groups and not just the one of the group. Given the properties of $\gamma(\cdot)$ and $\kappa(\cdot)$, we have $I_{h}>I_{l}, \kappa_{h}(Y)>\kappa_{l}(Y)$, and both $\kappa_{l}^{\prime}(Y)>0$ and $\kappa_{h}^{\prime}(Y)>0$.

What level of state capacity can we expect under different conditions and, specifically, under different patterns of social identification? Under group identification, inter-group conflict is expected, so it is natural to assume that investments in state capacity are chosen non-cooperatively in a Nash equilibrium. Thus, under group identification the material payoffs of each group are the same: ${ }^{23}$

$$
v \equiv \pi_{J}^{m}\left(\kappa_{l}(Y)\right)=\gamma\left(\kappa_{l}(Y)\right) Y-\frac{I_{l}-I_{-}}{2} ; J=A, B
$$

Furthermore, these material payoffs under group identification are the sole payoffs, with its other components of status and distance, as discussed below, normalized to be 0 . Furthermore, $v$ in (15) is increasing in gross income $Y$ since $\gamma(\cdot)$ is increasing and $\kappa_{l}^{\prime}(Y)>0$ (as $Y$ rises, the material payoff under group identification increases because there is greater state capacity and fewer resources wasted).

The material payoffs under national identification will be higher than $v$ in (15) if state capacity (and investments in it) were to be higher than they are under the noncooperative equilibrium. It is reasonable to suppose that the higher is national status $\sigma$ and the lower is the distance cost $\Delta$, the easier should be for the two groups to cooperate to raise state capacity above $\kappa_{l}(Y)$ and closer to the collectively optimal level $\kappa_{h}(Y)$. That is, investments in state capacity under national identification are an increasing function $\kappa^{N}(s ; Y)$ of the difference $s \equiv \sigma-\Delta$. Moreover, for simplicity of exposition we suppose that if status minus distance under national identification is exactly $0(s=0)$, state capacity is identical under national identification than it is under group identification. Therefore, national identification would yield lower costs of domestic conflict and higher material payoffs than group identifi-

\footnotetext{
${ }^{23} I_{l}$ denotes the Nash equilibrium total investment in state capacity. We suppose throughout this paper that this investment is shared by the two sides. With $I_{-}$denoting the inherited level of state capacity, each group's share of investment in state capacity is $\frac{I_{l}-I_{-}}{2}$.
} 
cation, provided that national status is high enough and distance from the nation low enough so that $s>0 .{ }^{24}$ The material payoffs under national identification are thus:

$$
V(s) \equiv \pi_{J}^{m}\left(\kappa^{N}(s ; Y)\right)=\gamma\left(\kappa^{N}(s ; Y)\right) Y-\frac{I_{N}(s)-I}{2} ; J=A, B
$$

where $I_{N}(s)$ is the total investment under national identification (increasing in $s$ ). Clearly, since these investments are increasing in $s$ and are less than the collectively optimal level $\kappa_{h}(Y)$, the material payoff under national identification $V(s)$ is also increasing in $s$ (for $s>0)$. We have thus derived the material payoffs $v$ and $V(s)$ appearing in (1).

Proof of Proposition 2, part (ii): The effect of $c$ is obvious, since the lower the right-hand-side is the more likely is for the inequality to hold.

We will consider the effects of $V\left(s^{\nu}\right)-v$ and $s^{v}$ by differentiating the left-hand-side of (12) to obtain:

$$
\begin{aligned}
& \frac{\partial \frac{\left[2\left(V\left(s^{\nu}\right)+s^{\nu}-v\right)+d\right]\left[2\left(V\left(s^{\nu}\right)+s^{\nu}-v\right)-d\right]}{2\left(V\left(s^{\nu}\right)+s^{\nu}-V\right)+3 d}}{\partial\left(V\left(s^{\nu}\right)-v\right)}= \\
& =\frac{2\left[2\left(V\left(s^{\nu}\right)+s^{\nu}-v\right)-d\right]+2\left[2\left(V\left(s^{\nu}\right)+s^{\nu}-v\right)+d\right]}{2\left(V\left(s^{\nu}\right)+s^{\nu}-v\right)+3 d}-\frac{2\left[2\left(V\left(s^{\nu}\right)+s^{\nu}-v\right)+d\right]\left[2\left(V\left(s^{\nu}\right)+s^{\nu}-v\right)-d\right]}{\left[2\left(V\left(s^{\nu}\right)+s^{\nu}-v\right)+3 d\right]^{2}} \\
& =\frac{8\left(V\left(s^{\nu}\right)+s^{\nu}-v\right)\left[2\left(V\left(s^{\nu}\right)+s^{\nu}-v\right)+3 d\right]-2\left[4\left(V\left(s^{\nu}\right)+s^{\nu}-v\right)^{2}-d^{2}\right]}{\left[2\left(V\left(s^{\nu}\right)+s^{\nu}-v\right)+3 d\right]^{2}} \\
& =\frac{16\left(V\left(s^{\nu}\right)+s^{\nu}-v\right)^{2}+24\left(V\left(s^{\nu}\right)+s^{\nu}-v\right) d-8\left(V\left(s^{\nu}\right)+s^{\nu}-v\right)^{2}+2 d^{2}}{\left[2\left(V\left(s^{\nu}\right)+s^{\nu}-v\right)+3 d\right]^{2}} \\
& =\frac{8\left(V\left(s^{\nu}\right)+s^{\nu}-v\right)^{2}+24\left(V\left(s^{\nu}\right)+s^{\nu}-v\right) d+2 d^{2}}{\left[2\left(V\left(s^{\nu}\right)+s^{\nu}-v\right)+3 d\right]^{2}}>0 \text { (since all terms in the numerator and denominator }
\end{aligned}
$$

are positive).

Next, consider

$$
\begin{aligned}
& \frac{\partial \frac{\left[2\left(V\left(s^{\nu}\right)+s^{\nu}-v\right)+d\right]\left[2\left(V\left(s^{\nu}\right)+s^{\nu}-v\right)-d\right]}{2\left(V\left(s^{\nu}+s^{\nu}-V\right)+3 d\right.}}{\partial s^{\nu}}= \\
& =\frac{2\left(V^{\prime}\left(s^{\nu}\right)+1\right)\left(V\left(s^{\nu}\right)+s^{\nu}-v-d+V\left(s^{\nu}\right)+s^{\nu}-v+d\right)}{2\left(V\left(s^{\nu}\right)+s^{\nu}-v\right)+3 d}-\frac{2\left(V^{\prime}\left(s^{\nu}\right)+1\right)\left[2\left(V\left(s^{\nu}\right)+s^{\nu}-v\right)+d\right]\left[2\left(V\left(s^{\nu}\right)+s^{\nu}-v\right)-d\right]}{\left[2\left(V\left(s^{\nu}\right)+s^{\nu}-v\right)+3 d\right]^{2}} \\
& =\frac{\left(V^{\prime}\left(s^{\nu}\right)+1\right)\left[2\left(V\left(s^{\nu}\right)+s^{\nu}-v\right)\left[2\left(V\left(s^{\nu}\right)+s^{\nu}-v\right)+3 d\right]-4\left(V\left(s^{\nu}\right)+s^{\nu}-v\right)^{2}+d^{2}\right]}{\left[2\left(V\left(s^{\nu}\right)+s^{\nu}-v\right)+3 d\right]^{2}} \\
& =\frac{\left(V^{\prime}\left(s^{\nu}\right)+1\right)\left[4\left(V\left(s^{\nu}\right)+s^{\nu}-v\right)^{2}+6\left(V\left(s^{\nu}\right)+s^{\nu}-v\right) 3 d-4\left(V\left(s^{\nu}\right)+s^{\nu}-v\right)^{2}+d^{2}\right]}{\left[2\left(V\left(s^{\nu}\right)+s^{\nu}-v\right)+3 d\right]^{2}} \\
& =\frac{\left(V^{\prime}\left(s^{\nu}\right)+1\right)\left[6\left(V\left(s^{\nu}\right)+s^{\nu}-v\right) 3 d+d^{2}\right]}{\left[2\left(V\left(s^{\nu}\right)+s^{\nu}-v\right)+3 d\right]^{2}}>0\left(\text { since } V^{\prime}\left(s^{\nu}\right)>0\right. \text { and all the terms inside the brackets }
\end{aligned}
$$

in the numerator are positive and the denominator is positive).

\footnotetext{
${ }^{24}$ State capacity could also affect both status and distance through, for example, expenditures on public education that emphasize national identification by reducing ethnic or regional differences. This could be handled in our model by having $s$ depend on $\kappa$. The model would be more complex but our results would be unaffected.
} 
Therefore, the effect of an increase of $V\left(s^{\nu}\right)-v$ or $s^{v}$ is to increase the left-hand-side and thus increase the chance of War. 


\section{REFERENCES}

Applegate, Celia. 1990. A Nation of Provincials: The German Idea of Heimat. Berkeley: University of California Press.

Banac, Ivo. 1983. The National Question on Yugoslavia. Ithaca: Cornell University Press.

Bettencourt, Ann, Kelly Charlton, Nancy Dorr, and Deborah Hume. 2001. "Status differences and in-group bias: A meta-analytic examination of the effects of status stability, status legitimacy, and group permeability." Psychological Bulletin 127: 520-542.

Becker, Josef, editor 2003. Bismarck's spanische "Diversion" 1870 und der preussichdeutsch Reichsgruendungskrieg: Quellen zur Vor- und Nachgeschichte der HohenzollernKandidatur fuer den Thron in Madrid 1866-1932 Munich: Schoeningh.

Becker, Josef, 2008 "Exchange: Bismarck and the Franco Prussian War," Central European History 41 93-109.

BESLEY, Timothy and Persson, Torsten. 2011. Pillars of Prosperity: The Political Economics of Development Clusters, Princeton: Princeton University Press.

Binmore, Ken, Rubinstein, Ariel and Wolinsky, Asher. 1986. "The Nash Bargaining Solution in Economic Modelling." The RAND Journal of Economics, 17(2): 176-188.

Böhme, Helmut. 1971. The Foundation of the German Empire: Select Documents. Oxford: Oxford University Press.

Bornstein, Gary. 2003. "Intergroup Conflict: Individual, Group, and Collective Interests." Personality and Social Psychology Review 7 (2): 129-45.

Brewer, Marilynn B. 1979. "In-Group Bias in the Minimal Group Situation: A CognitiveMotivational Analysis." Psychological Bulletin 86: 307-24.

Bourhis, Richard Y. and Gagnon, Andre. 2001. "Social orientations in the minimal group paradigm". In R. Brown and S. Gaertner, eds., Intergroup processes: Blackwell handbook in social psychology (Vol. 4), Oxford, UK: Blackwell, pp. 89-111. 
Bruce Bueno de Mesquita and Alastair Smith 2012. "Domestic Explanations of International Relations." Annual Review of Political Science 15:161-81.

Cardoza, Anthony. 2000. "Cavour and Piedmont." In John A. Davis, ed, Italy in the Nineteenth Century, 1796-1900. Oxford: Oxdord University Press, pp. 124-125.

Carr, William. 1991. The Origins of the Wars of German Unification. London: Longman.

Case, Lynn Marshall. 1954. French opinion on war and diplomacy during the Second Empire Philadelphia, University of Pennsylvania Press.

Clark, Christopher. 2006. Iron Kingdom: The Rise and Downfall of Prussia, 1600-194\%. Cambridge: Harvard University Press.

Collins, Randall. 1986. Weberian Sociological Theory Cambridge: Cambridge University Press.

Confino, Alon. 1997. The Nation as a Local Metaphor: Wurttemberg, Imperial Germany and National Memory, 1871-1918. Chapel Hill: University of North Carolina Press.

Dafoe, Allan, Jonathan Renshon, and Paul Huth. 2014. "Reputation and Status as Motives for War." Annual Review of Political Science forthcoming.

Dekmejian, R. Hrair. 1980. "The Anatomy of Islamic Revival: Legitimacy Crisis, Ethnic Conflict and the Search for Islamic Alternatives." The Middle East Journal pp. 1-12

Dincecco, Mark, Giovanni Federico, and Andrea Vindigni. 2011. "Warfare, Taxation, and Political Change: Evidence from the Italian Risorgimento." Journal of Economic History 71 (4): 887-914.

Echard, William E. 1983. Napoleon III and the Concert of Europe. Baton Rouge: Louisiana State University Press.

Eyck, Erich. 1950. Bismarck and rhe German Empire. London: Unwin.

Fearon, James. 1995. "Rationalist explanations for war," International Organization, 49(3): 379-414.

Fink, Erwin. 2005. "For Country, Court and Church: The Bavarian Patriots' Party and 
Bavarian Regional Identity in the Era of German Unification." In Ronald Speirs and John Breuilly, eds., Germany's Two Unifications: Anticipations, Experiences, Responses. New York: Palgrave Macmillan; pp. 155-171.

Finnemore, Martha. 1996. National Interests in International Society (Ithaca, NY: Cornell University Press.

Frank, Robert H. 1985. Choosing the Right Pond: Human Behavior and the Quest for Status. New York: Oxford University Press.

Fravel, Taylor. 2010. "The Limits of Diversion: Rethinking Internal and External Conflict." Security Studies 19:2 307-341.

Gaffney, Patrick D. 1992. "Popular Islam." Annals AAPSS 524 (November): 38-51.

Gall, Lothar. 1986. Bismarck: The White Revolutionary, Volume 1, 1851-1871. London: Allen \& Unwyn.

Garfinkel, Michelle R. and Stergios Skaperdas. 2000. "Conflict withoout Misperceptions or Incomplete Information: How the Future Matters." Journal of Conflict Resolution 44(6): 793-807.

Geyer, Dietrich. 1987. Russian Imperialism: The Interaction of Domestic and Foreign Policy, 1860-1914. Trans. Bruce Little. New Haven: Yale University Press.

Green, Abigail. 2005. "How Did German Federalism Shape Unification?" In Ronald Speirs and John Breuilly, eds., Germany's Two Unifications: Anticipations, Experiences, Responses. New York: Palgrave Macmillan; pp. 122-138.

Hechter, Michael. 2001. Containing Nationalism. Oxford: Oxford University Press.

Hirshleifer, J. 1989. "Conflict and rent-seeking success functions: Ratio vs. difference models of relative success," Public Choice 63: 101-112.

Hobbes, Thomas. 1991. Leviathan ed. Richard Tuck, Cambridge University Press.

Holt, Edgar 1970. Risorgimento: TheMaking of Italty, 1815-1870. Macmillan.

Horowitz, Donald L. 1985. Ethnic Groups in Conflict. Berkeley: University of California Press. 
Howard, Michael. 1962. The Franco-Prussian War: The German Invasion of France, 1870-1871. London: Rupert Hart-Davis.

Ibrahim, Saad Eddin. 1988. "Egypt's Islamic Activism in the 1980s." Third World Quarterly 10 (2): 632-657.

Jia, Hao, Skaperdas, Stergios, and Vaidya, Samarth. 2013. "Contest Functions: Theoretical Foundations and Issues in Estimation." International Journal of Industrial Organization 31: $211-222$.

Jian, Chen. 1994. China's Road to the Korean War: The Making of the Sino-American Confrontation. New York: Columbia University Press.

Katzenstein, Peter J. 1976. Disjoined Partners: Austria and Germany Since 1815 Berkeley: University of California Press.

Konrad, K. A. 2009. Strategy and Dynamics in Contests. New York: Oxford University Press.

Levy, Jack S. 1989. "The Diversionary Theory of War: A Critique." In Manus A. Midlarsky, Handbook of War Studies. Boston: Allen \& Unwin; pp. 259-288.

Lieberthal, Kenneth. 2004. Governing China: From Revolution Through Reform. Second edition. New York: Norton.

Lieven, D.C.B. 1983. Russian and the Origins of the First World War. New York: MacMillan.

Markey, Daniel S. 2000. "The Prestige Motive in International Relations" Ph.D. dissertation. Princeton University.

McBride, Michael, Gary Milante and Stergios Skaperdas. 2011. "Peace and War with Endogenous State Capacity." Journal of Conflict Resolution 55(3): 446-468.

McBride, Michael and Stergios Skaperdas. 2007. "Explaining Conflict in Low-Income Countries: Incomplete Contracting in the Shadow of the Future." In M. Gradstein and K.A. Konrad, (eds.), Institutions and Norms in Economic Development. Cambridge, MA: MIT Press; 141-161. 
Mearsheimer, John J. 2006. "Structural Realism." In Tim Dunne, Milja Kurki, and Steve Smith, eds., International Relations Theories: Discipline and Diversity. Oxford: Oxford University Press; pp. 71-88.

Meinecke, Friedrich. 1957. Machiavellism: The Doctrine of Raison d'etat and its Place in Modern History. New Haven: Yale University Press.

Mercer, Jonathan. 1995. "Anarchy and Identity." International Organization 49 (2): 229-252.

Mylonas, Harris. 2013. The Politics of Nation-Building: Making Co-Nationals, Refugees, and Minorities. Cambridge: Cambridge University Press.

Pflantze, Otto 1990. Bismarck and the Development of Germany, vol. 1, The Period of Unification, 1815-1871. Princeton: Princeton University Press.

Posen, Barry R. 1993. "Nationalism, the Mass Army, and Military Power." International Security 18 (2): 80-124.

Price, Roger 2001.The French Second Empire: An Anatomy of Political Power. Cambridge: Cambridge University Press.

Sambanis, Nicholas, Jonah Schulhofer-Wohl, and Moses Shayo. 2012. "Parochialism as a Central Challenge in Counterinsurgency." Science 336 (6083): 805-08.

Sambanis, Nicholas and Moses Shayo. 2013. "Social Identification and Ethnic Conflict." American Political Science Review 107 (2): 294-325.

Shayo, Moses. 2009. "A Model of Social Identity with an Application to Political Economy: Nation, Class and Redistribution." APSR 103 (2): 147-174.

Skaperdas, Stergios. 2006. "Bargaining vs. Fighting." Defense and Peace Economics. December, 17 (6).

Snyder, Jack L. 1991 Myths of Empire: Domestic Politics and International Ambition. Cornell University Press.

Snyder, Jack L. and Edward Mansfield. 2005. Electing to Fight: Why Emerging Democracies Go to War. Cambridge: MIT Press. 
Spence, Jonathan D. 1990. In Search of Modern China. 2nd edition. New York: Norton.

Steefel, Lawrence. 1962. Bismarck, the Hohenzollern Candidacy, and the Origins of the Franco-German War of 1870. Cambridge: Harvard University Press.

Steinberg, Jonathan. 2001. Bismarck: A Life Oxford: Oxford University Press.

Tajfel, Henri, and John Turner. 1986. "The Social Identity Theory of Intergroup Behavior." In Worchel S. and W. Austin, eds. Psychology of Intergroup Relations. Chicago: Nelson Hall, 7-24.

Tajfel, Henri, Michael G. Billig, Robert P. Bundy, and Claude Flament. 1971. "Social Categorization and Intergroup Behavior." European Journal of Social Psychology 1(2): 149178.

Wawro, Geoffrey. 2003. The Franco-Prussian War: The German Conquest of France in 1870-1871. Cambridge: Cambridge University Press.

Weber, Max. 1978 [1924]). Economy and Society: An Outline of Interpretive Sociology. Berkeley: University of California Press.

Weichlein, Siegfried. 2000. "Saxons into Germans: The Progress of the National Idea in Saxony after 1866." In James Retallack, ed., Saxony in German History: Culture, Society and Politics, 1830-1933. Ann Arbor: University of Michigan Press , pp. 166-79.

Wetzel, David. 2001 A Duel of Giants: Bismarck, Napoleon III, and the Origins of the Franco-Prussian War. Maddison: University of Wisconsin Press.

Wendt, Alex. 1999. Social Theory of International Politics. Cambridge, Cambridge University Press.

Wimmer, Andreas. 2013. Waves of War: Nationalism, State Formation, and Ethnic Exclusion in the Modern World. Cambridge: Cambridge University Press.

Wimmer, Andreas. 2008. "The Making and Unmaking of Ethnic Boundaries: A Multilevel Process Theory." American Journal of Sociology 113(4): 970-1022.

Zhang, Shu Guang. 1995. Mao's Military Romanticism: China and the Korean War, 1950-1953. Lawrence: University Press of Kansas 


\section{Supplementary Appendix for "Nation-Building through War": Additional Cases of Proposition 1 and Interaction of France and Germany under an Indefinite Horizon}

\section{Cases III-IV of Proposition 1}

Below, we present three of the five cases of the model of inter-state conflict with endogenous social identification. As in the main text, the focus is on whether Peace would be a feasible outcome.

Case III: Group identification in $G$ occurs only after loss in War

This case occurs when $\left(V\left(s^{\nu}\right)+s^{\nu}>\right) V\left(s^{p}\right)+s^{p} \geq v>V\left(s^{l}\right)+s^{l}$. It yields national identification under Peace and after victory in War and ethnic identification after loss in War. The payoff of $G$ then in this case becomes:

$$
\begin{aligned}
& V_{P}^{G_{I I I}}=V\left(s^{p}\right)+s^{p}+\beta d+t \\
& V_{W}^{G_{I I I}}=p\left(V\left(s^{\nu}\right)+s^{\nu}+d\right)+(1-p) v-c
\end{aligned}
$$

As with the previous cases, Peace is feasible only when $V_{P}^{F}+V_{P}^{G_{I I I}} \geq V_{W}^{F}+V_{W}^{G_{I I I}}$ or:

$$
\begin{aligned}
V\left(s^{p}\right)+s^{p}+d & \geq p\left(V\left(s^{\nu}\right)+s^{\nu}\right)+(1-p) v+d-2 c \\
\text { or } 2 c & \geq p\left(V\left(s^{\nu}\right)+s^{\nu}\right)+(1-p) v-V\left(s^{p}\right)-s^{p}
\end{aligned}
$$

Given the parameter values for which this case occurs, the right-hand-side of (1) can be positive. As long as that is so, Peace is not feasible for small enough conflict costs $(c)$. However, contrary to case II, War cannot be assured for low enough values of $c$; the benefits from, and probability of, victory must be high enough.

Case IV: Group identification in $G$ occurs only when there is Peace

This case occurs when $\left(V\left(s^{\nu}\right)+s^{\nu}>\right) V\left(s^{l}\right)+s^{l} \geq v>V\left(s^{p}\right)+s^{p}$. It yields national identification after War regardless of whether there is victory or loss; and group identification under Peace. $G^{\prime} s$ payoff becomes:

$$
\begin{aligned}
& V_{P}^{G_{I V}}=v+\beta d+t \\
& V_{W}^{G_{I V}}=p\left(V\left(s^{\nu}\right)+s^{\nu}+d\right)+(1-p)\left(V\left(s^{l}\right)+s^{l}\right)-c
\end{aligned}
$$

As with the previous cases, Peace is feasible only when $V_{P}^{F}+V_{P}^{G_{I V}} \geq V_{W}^{F}+V_{W}^{G_{I V}}$ or:

$$
\begin{aligned}
& v+d \geq p\left(V\left(s^{\nu}\right)+s^{\nu}\right)+(1-p) v+d-2 c \\
& \text { or } 2 c \geq p\left(V\left(s^{\nu}\right)+s^{\nu}\right)+(1-p)\left(V\left(s^{l}\right)+s^{l}\right)-v
\end{aligned}
$$

Given that $V\left(s^{l}\right)+s^{l}>V\left(s^{p}\right)+s^{p}$ in this case, the right-hand-side of (2) is always positive and, therefore, War occurs for low enough costs. This case is qualitatively similar to case II.

Why is $V\left(s^{l}\right)+s^{l}>V\left(s^{p}\right)+s^{p}$ ?

For example, in the statement below for Case V, wouldn't the right hand side of the inequality have to be $v+s$ ? 
Case V: National identification always occurs in $G$

This case occurs when $\max \left\{V\left(s^{p}\right)+s^{p}, V\left(s^{l}\right)+s^{l}\right\}>v$, and always yields national identification with the following payoffs under Peace and War:

$$
\begin{aligned}
V_{P}^{G_{V}} & =V\left(s^{p}\right)+s^{p}+\beta d+t \\
V_{W}^{G_{V}} & =p\left(V\left(s^{\nu}\right)+s^{\nu}+d\right)+(1-p)\left(V\left(s^{l}\right)+s^{l}\right)-c
\end{aligned}
$$

Peace is feasible only if:

$$
\begin{aligned}
V\left(s^{p}\right)+s^{p}+d & \geq p\left(V\left(s^{\nu}\right)+s^{\nu}\right)+(1-p) v+d-2 c \\
\text { or } 2 c & \geq p\left(V\left(s^{\nu}\right)+s^{\nu}\right)+(1-p)\left(V\left(s^{l}\right)+s^{l}\right)-V\left(s^{p}\right)-s^{p}
\end{aligned}
$$

The condition for Peace in this case is qualitatively similar to that of case III in (1): Peace is not feasible when the right-hand-side of (3) is positive (with low enough costs of conflict) and that occurs when the convex combination of status under victory and under a loss is higher than status under Peace, with the weights depended on the probability of War. 


\section{Interaction of Germany and France under and Indefinite Horizon}

Next, we examine an indefinite-horizon version of the model with exogenous probabilities of victory and loss that is adapted to the interaction between France and Germany. We find similar results to those of Proposition 1 but, in addition, we find that when the shadow of the future (the discount) becomes longer, the set of parameter values over which Peace prevails becomes smaller.

The countries are interacting over an indefinite horizon. In each period, each country has the choice of either Peace or War. The sequence of moves in each period are the following:

1. France and Prussia simultaneousy choose either War or Peace. If both choose Peace, then Peace prevails. If at least one country chooses War, then War takes place. Prussia wins with probability $p>0$ and France wins with probability $1-p$. The winner keeps the disputed territory for all the subsequent periods.

2. a. After Peace, victory for Prussia after War, or loss for Prussia after War, $P$ and $S$ decide whether to unify or not.

b. If there is a unified Germany, its elites play a modification of the game in (1); i.e., they decide whether to identify with their region or the nation.

The game we are examining is a Markovian one with three possible states: Peace (induced by both France and Prussia choosing Peace); victory for France and loss for Prussia (induced by either country choosing War and "nature" choosing France as victor); and loss for France and victory for Prussia (induced by either country choosing War and "nature" choosing Prussia as victor). Note that the two latter states are absorbing states (that is, once you reach them you stay there forever). We will first specify and justify the per period payoffs and gradually build on equilibrium behavior. The winner of the war would take possession of the disputed territory not only in the current period but also in all future periods. ${ }^{1} \mathrm{We}$ suppose that next period's payoff is discounted by both countries by the same discount factor $\delta \in(0,1)$.

The solution concept we employ in such models is that of Markov Perfect Equilibrium (MPE). Peace is such an equilibrium only if the payoffs under Peace of both countries over the indefinite horizon are higher than those under War. War is always an equilibrium (since it takes only one side to choose War in order to have it and, therefore, trivially War is a best response to War). However, what we are primarily interested in (and show in the end) is whether Peace is feasible.

Next, however, we need to specify the payoffs and determine the equilibrium within Germany in stages $2 \mathrm{a}$ and $2 \mathrm{~b}$ (which is the same as stages $3 \mathrm{a}$ and $3 \mathrm{~b}$ in the main text but we produce here for completeness). We first suppose that the per-period material payoffs of $P$ and $S$, other than what comes from disputed territories are $v$ if Germany were not re-unified or if Germany were to be re-unified and $P$ or $S$ were to choose regional identification, and

\footnotetext{
${ }^{1}$ This assumption is made for computational simplicity, but it is also consistent with the case. Expectations at the time of the Franco-Prussian war were that disputed territory could be annexed by the victor. None of the qualitative results are affected with alternative assumptions such as that the winner takes possession of the disputed territory for a finite number of periods or has a constant (and high enough) exogenous probability of retaining possesion of the disputed territory.
} 
$V\left(s^{i}\right)+s^{i}(i=\nu, p, l)$ if Germany were to be re-unified and $P$ and $S$ were to choose national German identification. Thus, the per-period payoffs of $P$ and $S$ in stage $2 \mathrm{~b}$ are essentially identical to those in (5):

$$
\begin{array}{ccc} 
& G & S \\
G & V\left(s^{i}\right)+s^{i}+d^{i} / 2, V\left(s^{i}\right)+s^{i}+d^{i} / 2 & v+s^{i}+d^{i} / 2, v+d^{i} / 2 \\
P & v+d^{i} / 2, v+s^{i}+d^{i} / 2 & v+d^{i} / 2, v+d^{i} / 2
\end{array}
$$

where $i=\nu, p, l$ and $d^{i}$ represents the payoffs that come from the disputed territories in each state of the world, with $d^{\nu}=d, d^{p}=\beta d$, and $d^{l}=0$. We have assumed that under unification, the per-capita payoffs are distributed equally between Prussian/Northern Germans $(P)$ and Southern Germans $(S)$, providing an incentive for Southern elites to cooperate. Moreover, since the values of $d^{i} / 2$ are the same in each cell, the equilibria we select are the same as in (5): Regional identification when $v>V\left(s^{i}\right)+s^{i}$ and national identification when $v>V\left(s^{i}\right)+s^{i}$.

In fact, consistent with the Franco-Prussia case evidence, we suppose in this section that $V\left(s^{\nu}\right)+s^{\nu}>v \geq \max \left\{V\left(s^{p}\right)+s^{p}, V\left(s^{l}\right)+s^{l}\right\}$ (corresponding to case II of the previous section) whereby national identification with Germany could occur only after victory in War.

Given that, the decision to unify in stage 2a, would depend on the expectation of the level of identification in stage $2 \mathrm{~b}$. In particular, in the case of victory in War, the per-period payoffs of the two sides ( $P$ is taken as the row player and $S$ as the column player) woulf be as follows:

$$
\begin{array}{ccc} 
& \text { Unify } & \text { Not unify } \\
\text { Unify } & V\left(s^{\nu}\right)+s^{\nu}+d / 2, V\left(s^{\nu}\right)+s^{\nu}+d / 2 & v+s^{\nu}+d / 2, v+d / 2 \\
\text { Not unify } & v+d / 2, v+s^{\nu}+d / 2 & v+d / 2, v+d / 2
\end{array}
$$

where we have assumed (but without loss of generality) that in the event of no unification Prussia would receive half of the benefit from the disputed territories. Since $V\left(s^{\nu}\right)+s^{\nu}>v$, Unification is the Pareto optimal equilibrium and we suppose from now on that Germany would unify after victory in War. Similarly, and without going through all the details, Germany would not unify in the cases of Peace and loss after War. The per-period payoffs of Prussia in the case of Peace would be $v+\beta d$ and in the case of loss after War would be just $v$.

We are now ready to specify the indefinite horizon payoffs under War and Peace for the two states. If War were to occur in the current period, France's expected payoff over the whole horizon would be the following:

$$
\begin{aligned}
V_{F}^{w} & =(1-p) \sum_{t=0}^{\infty} \delta^{t} d-c \\
& =(1-p) \frac{d}{1-\delta}-c
\end{aligned}
$$

Letting $\tau_{t}$ denote a possible transfer from France to Prussia in period $t,{ }^{2}$ if Peace were

\footnotetext{
${ }^{2}$ These transfers would not have to take the form of tribute but could involve the concession of a preferential trade arrangement to the other country or other such indirect mechanisms.
} 
to prevail this period as well as every future period, France's payoff would be:

$$
\begin{aligned}
V_{F}^{p} & =\sum_{t=0}^{\infty} \delta^{t}\left((1-\beta) d-\tau_{t}\right) \\
& =\frac{(1-\beta) d}{1-\delta}-\sum_{t=0}^{\infty} \delta^{t} \tau_{t}
\end{aligned}
$$

Turning to Prussia, its expected payoff under war would be the following:

$$
\begin{aligned}
V_{P}^{w} & =p \sum_{t=0}^{\infty} \delta^{t}\left(V\left(s^{\nu}\right)+s^{\nu}+d / 2\right)+(1-p) \sum_{t=0}^{\infty} \delta^{t} v-c \\
& =(1-p) \frac{v}{1-\delta}+p \frac{V\left(s^{\nu}\right)+s^{\nu}+d / 2}{1-\delta}-c
\end{aligned}
$$

With Peace in the current and all future periods, the payoff of Prussia would be:

$$
V_{P}^{p}=\sum_{t=0}^{\infty} \delta^{t}\left(v+\beta d+\tau_{t}\right)=\frac{v+\beta d}{1-\delta}+\sum_{t=0}^{\infty} \delta^{t} \tau_{t}
$$

Peace can be feasible only the sum of the payoffs under Peace $\left(V_{F}^{p}+V_{P}^{p}\right)$ are greater than the sum the payoffs under War $\left(V_{F}^{w}+V_{P}^{w}\right)$, or only if:

$$
p\left(V\left(s^{\nu}\right)+s^{\nu}-v-d / 2\right) \leq 2(1-\delta) c
$$

We summarize the implications of this inequality in the following Proposition (noting that $\left.s^{\nu} \equiv \sigma^{\nu}-\Delta^{\nu}\right)$ :

Proposition S: Even if transfers between the countries were possible, there are no transfers that would prevent war if (4) were not to be satisfied. In such a case, War would be more likely

(i) the higher is the status of a unified nation after victory in war $\left(\sigma^{\nu}\right)$

(ii) the lower is the perceived distance between regions after victory in war $\left(\Delta^{\nu}\right)$

(iii) the higher are the economic gains from unification $\left(V\left(s^{\nu}\right)\right)$

(iv) the higher is the discount factor $(\delta)$

(v) the lower are the costs of war (c)

(vi) the higher is the probability of winning $(p)$.

Note that War may be impossible to avoid even when there are no disputed territories $(d=0)$. In fact, $(4)$ is less likely to be satisfied the smaller $d$ is. $^{3}$

\footnotetext{
${ }^{3}$ This occurs because Prussia does not completely enjoy the territorial benefits of a victory and shares them, after unification, with $S$.
} 